\title{
Oxazolidines as intermediates in the asymmetric synthesis of 3- and 1,3-disubstituted tetrahydroisoquinolines
}

S. Raghavan* and Puspamitra Senapati

Natural Products Chemistry Division, Indian Institute of Chemical Technology, Hyderabad500007, India.

sraghavan@iict.res.in

Table of Contents

${ }^{1} \mathrm{H}$ NMR and ${ }^{13} \mathrm{C}$ NMR spectra
Page No.

S2-S39 
Compound 4
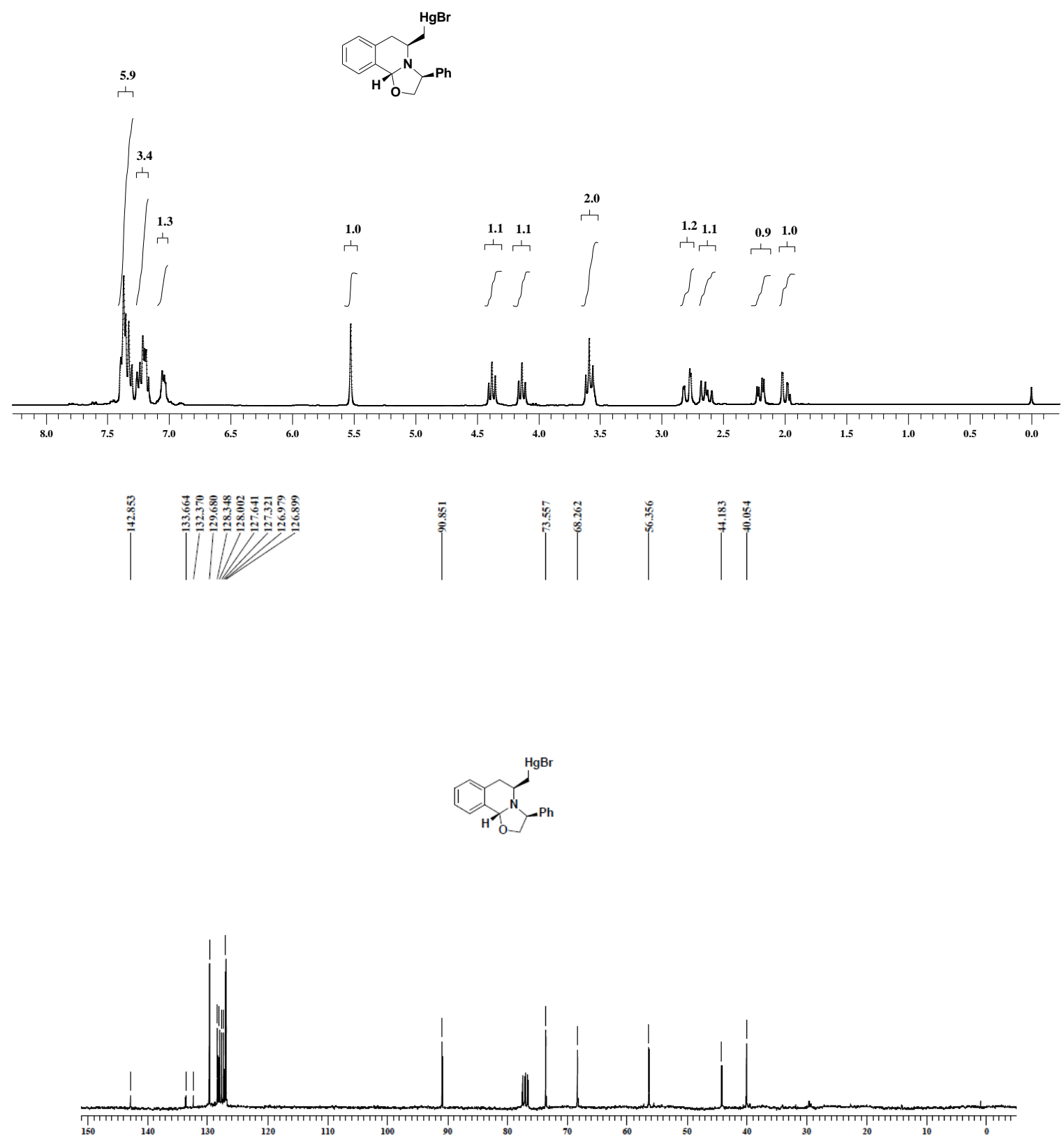


\section{Compound 4}
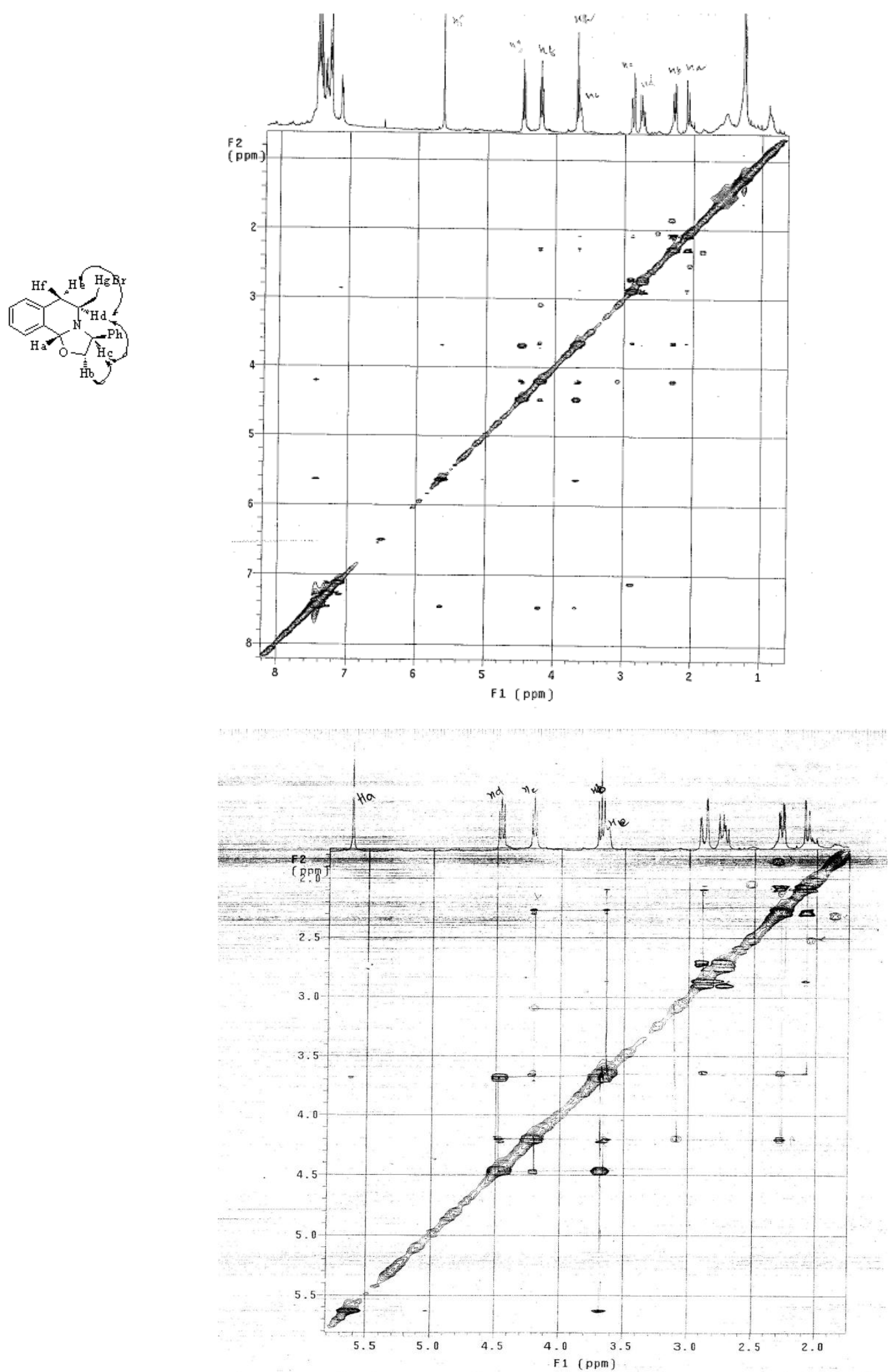


\section{Compound 13}
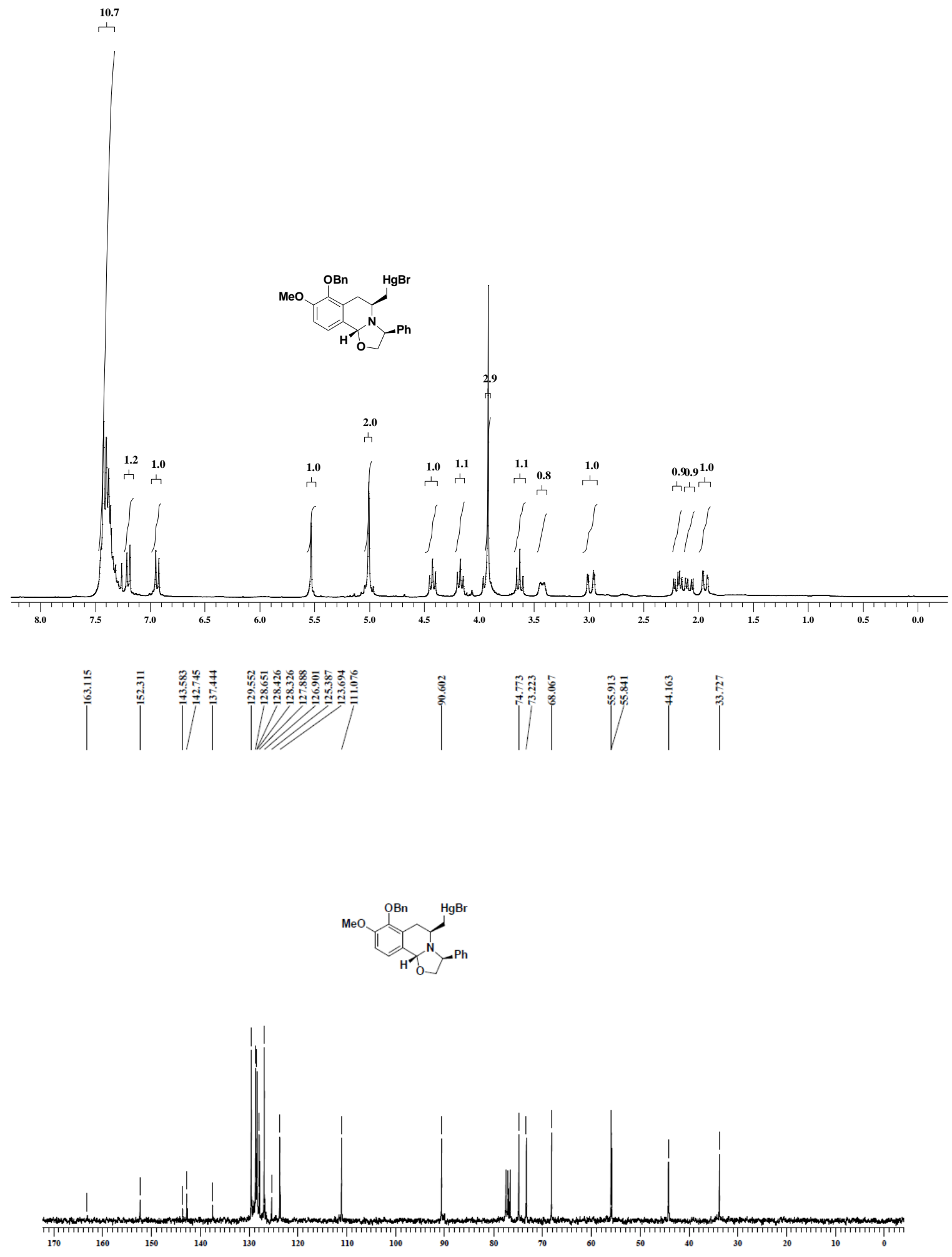


\section{Compound 15}
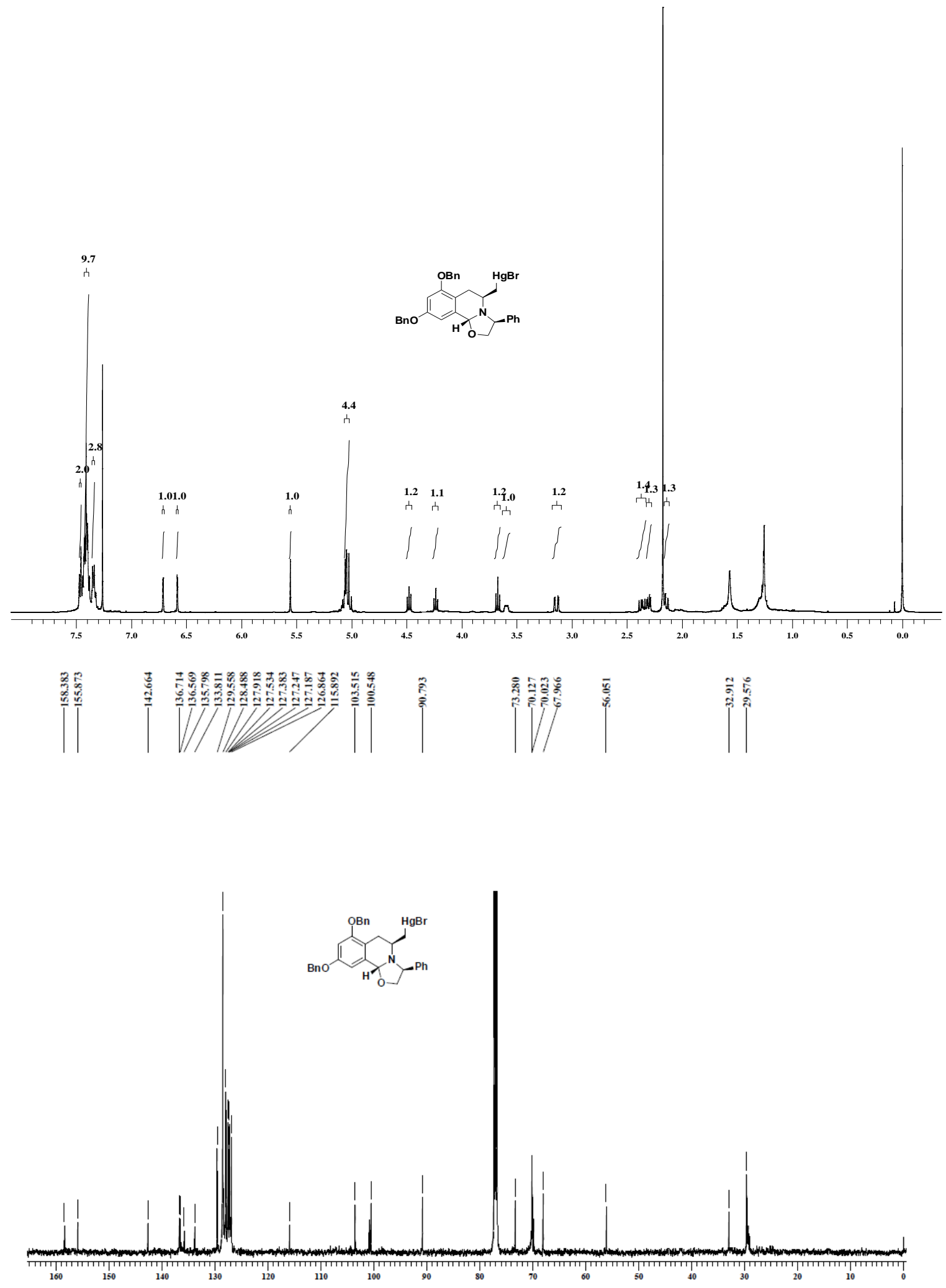
Compound 17
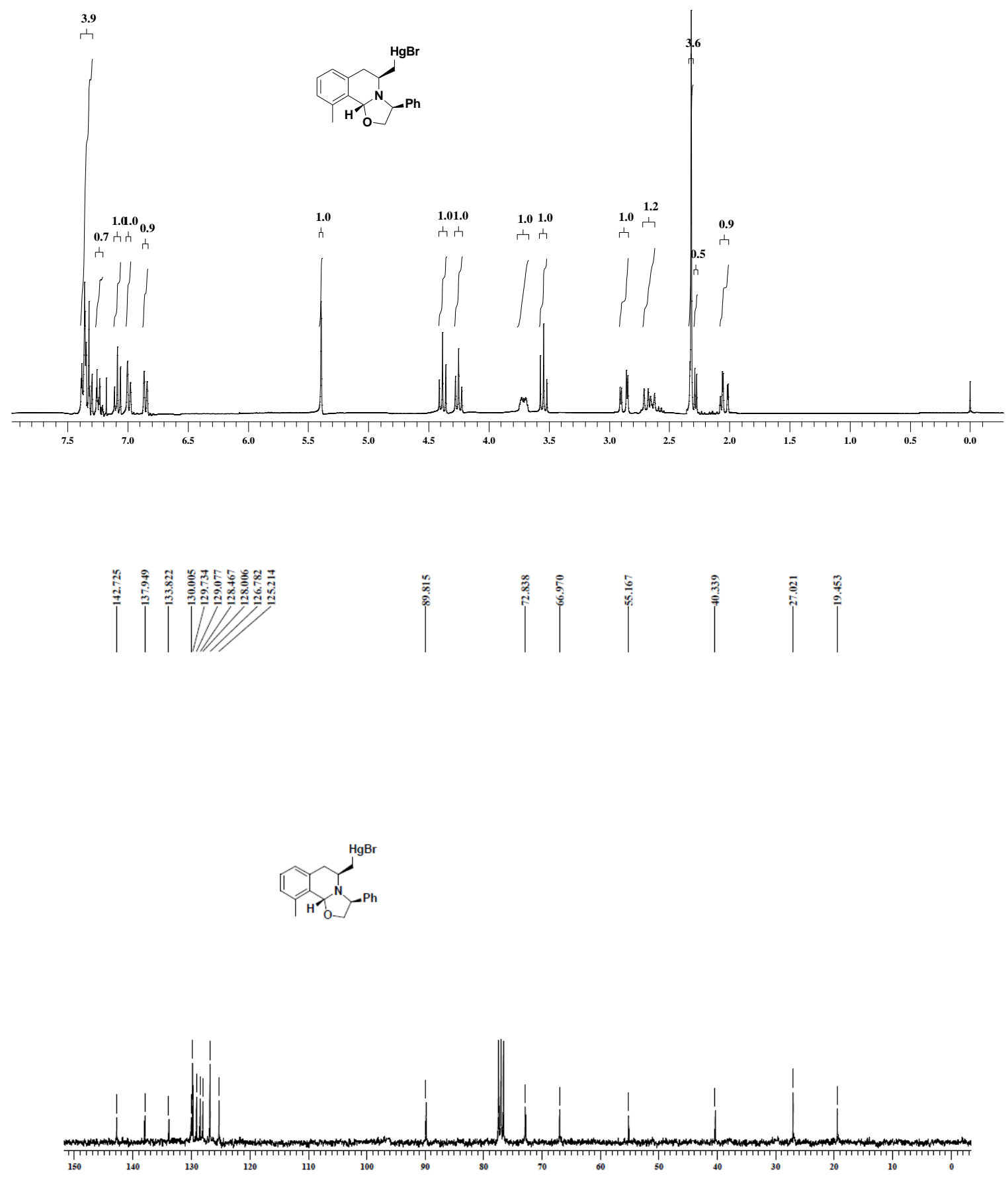


\section{Compound 20}
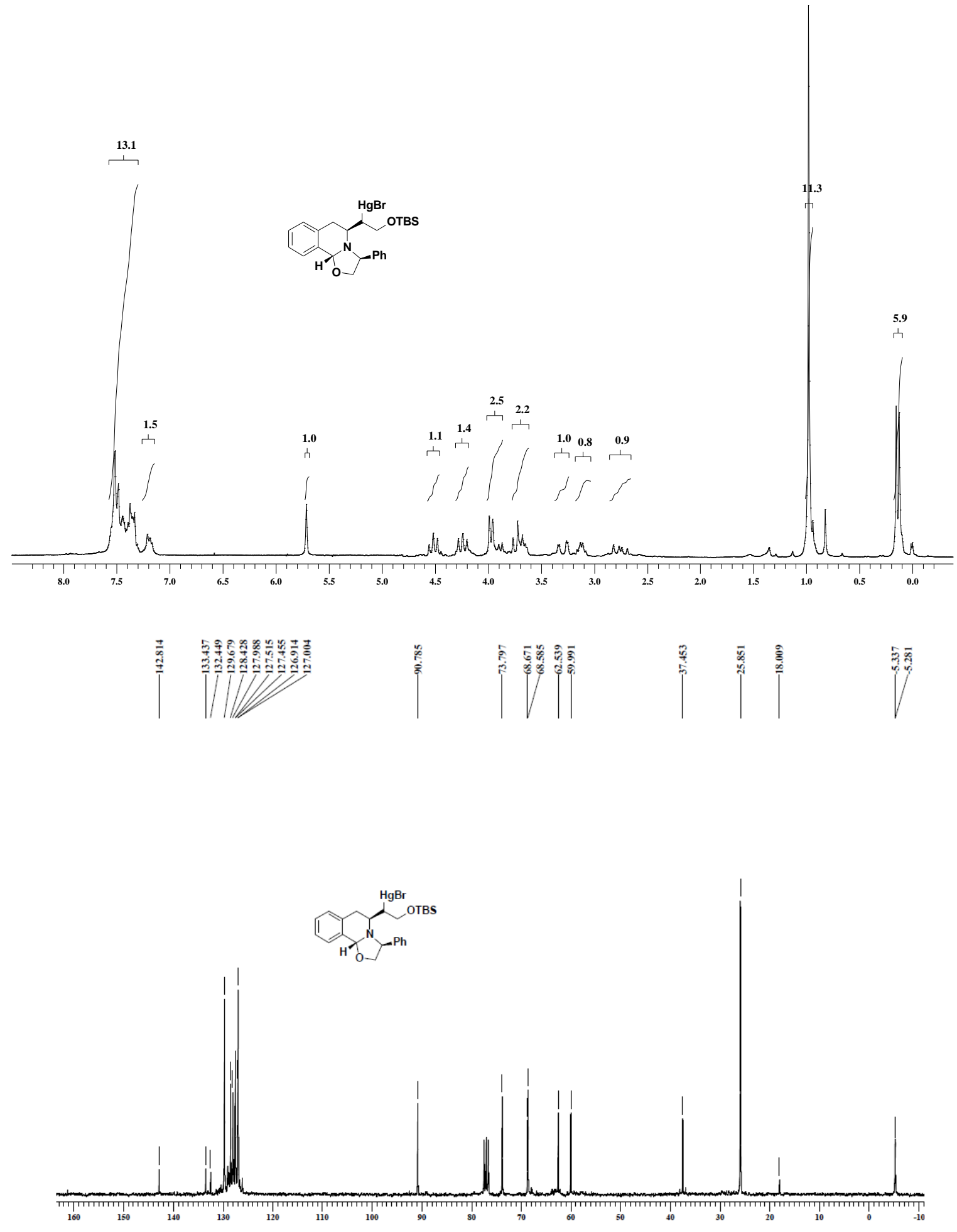


\section{Compound 22}
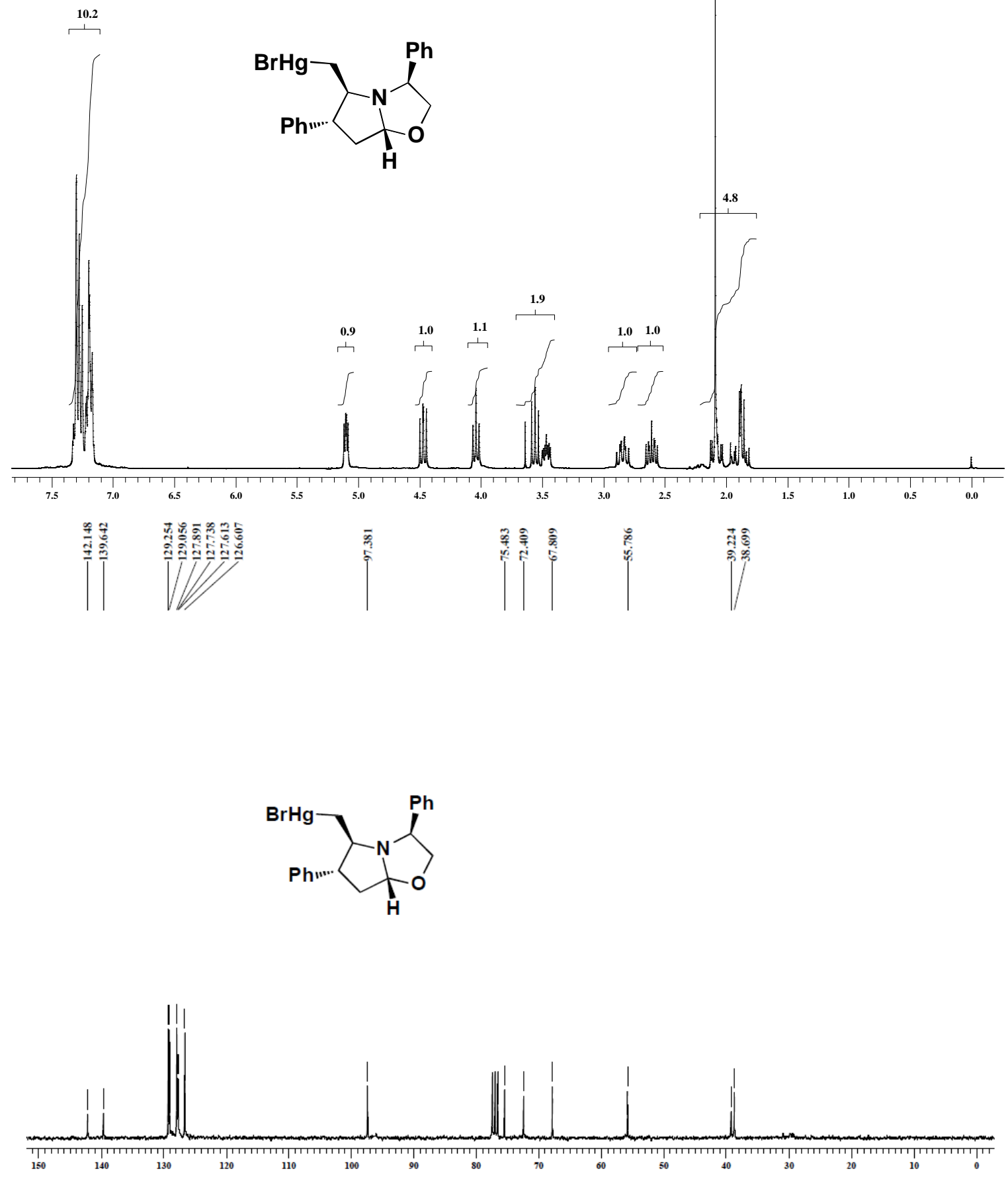


\section{Compound 22}
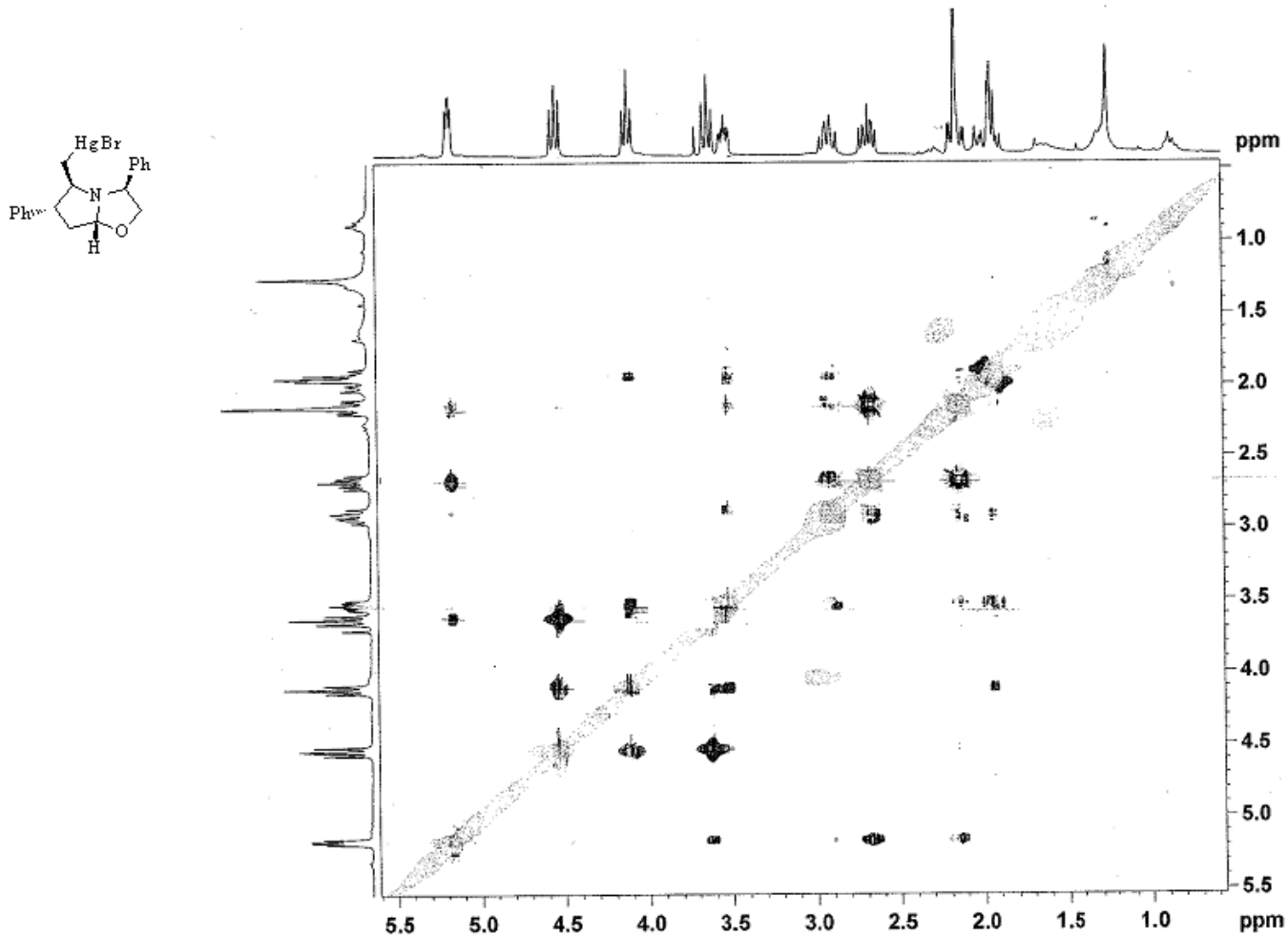
Compound 23
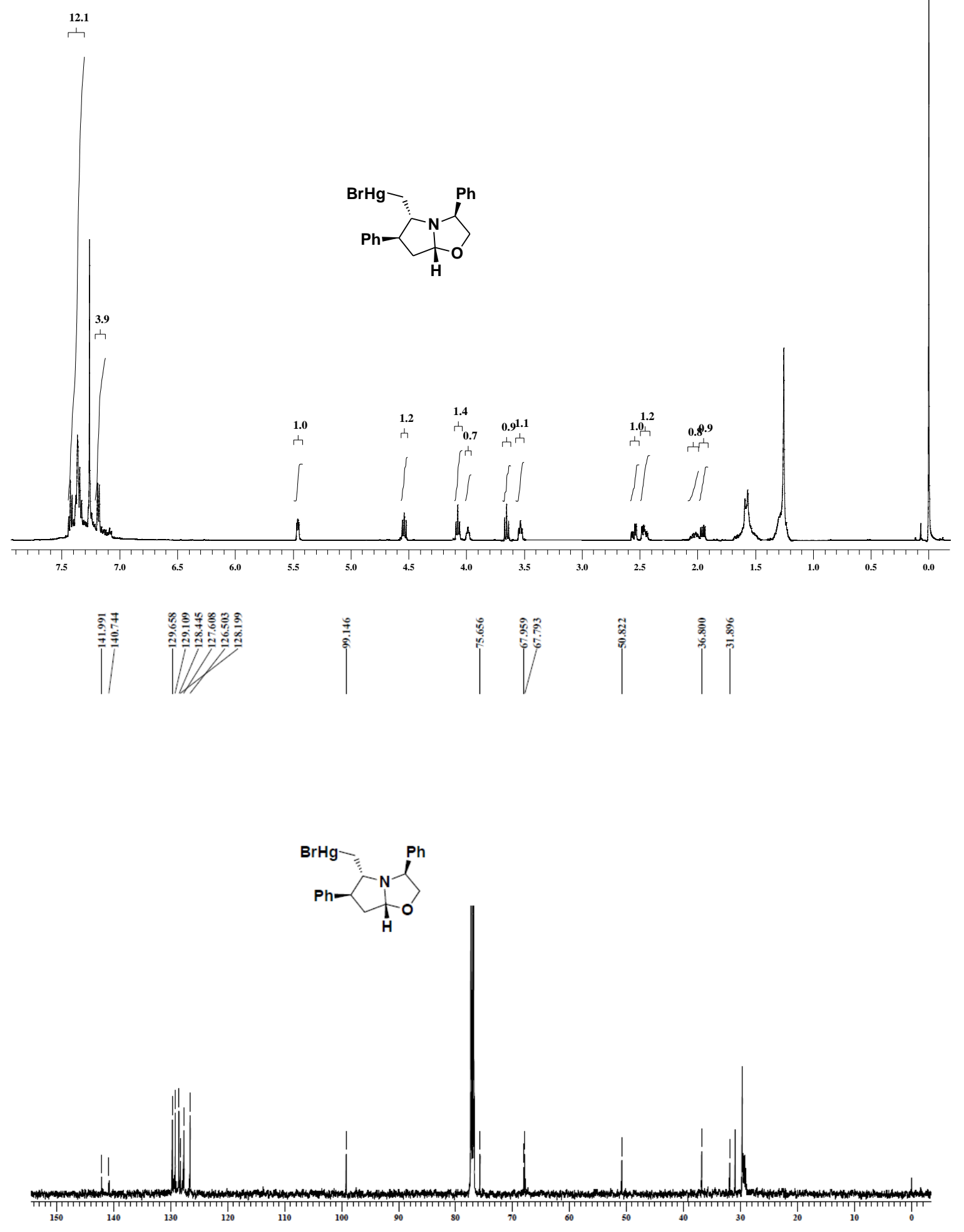
Compound 5
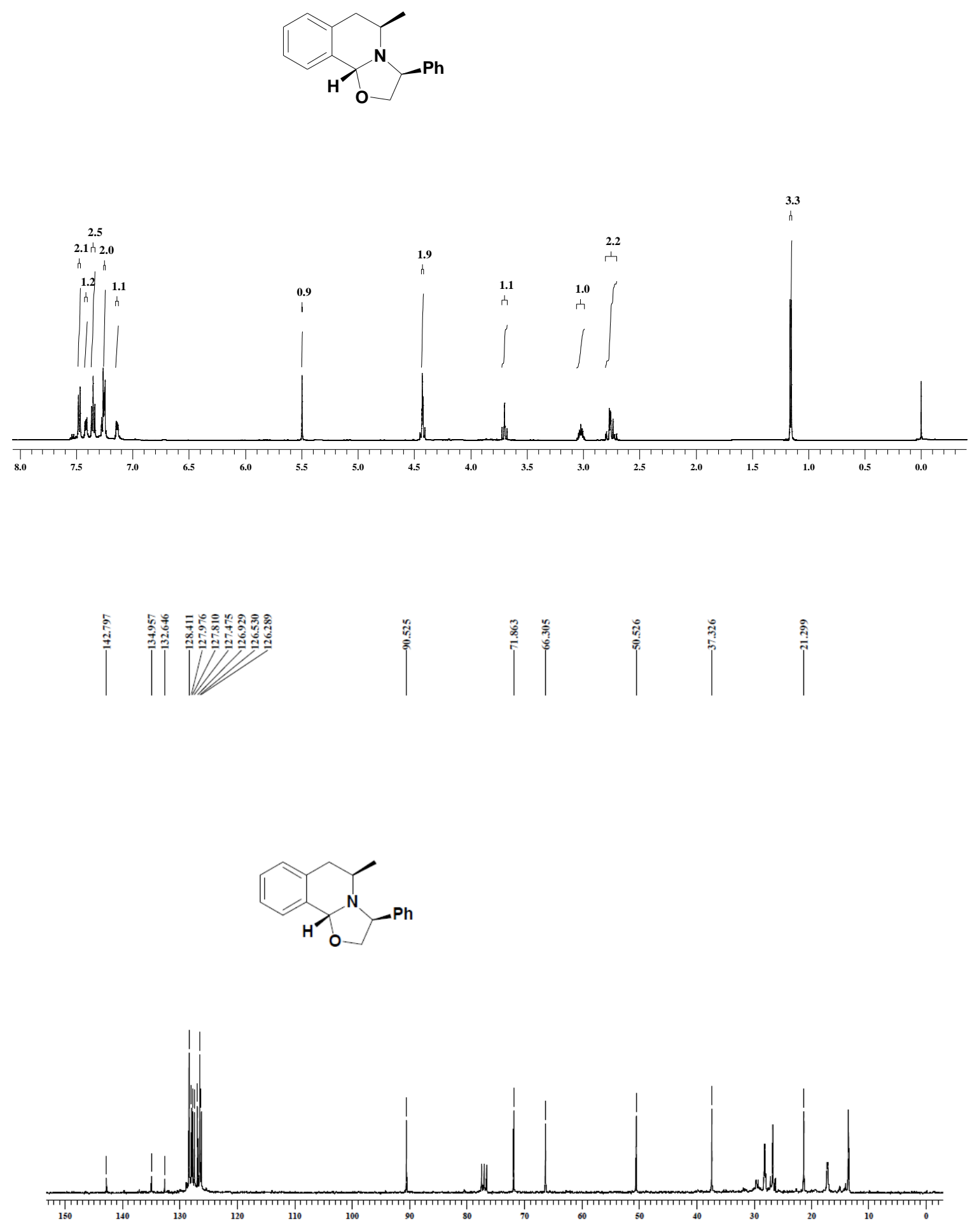


\section{Compound 9}
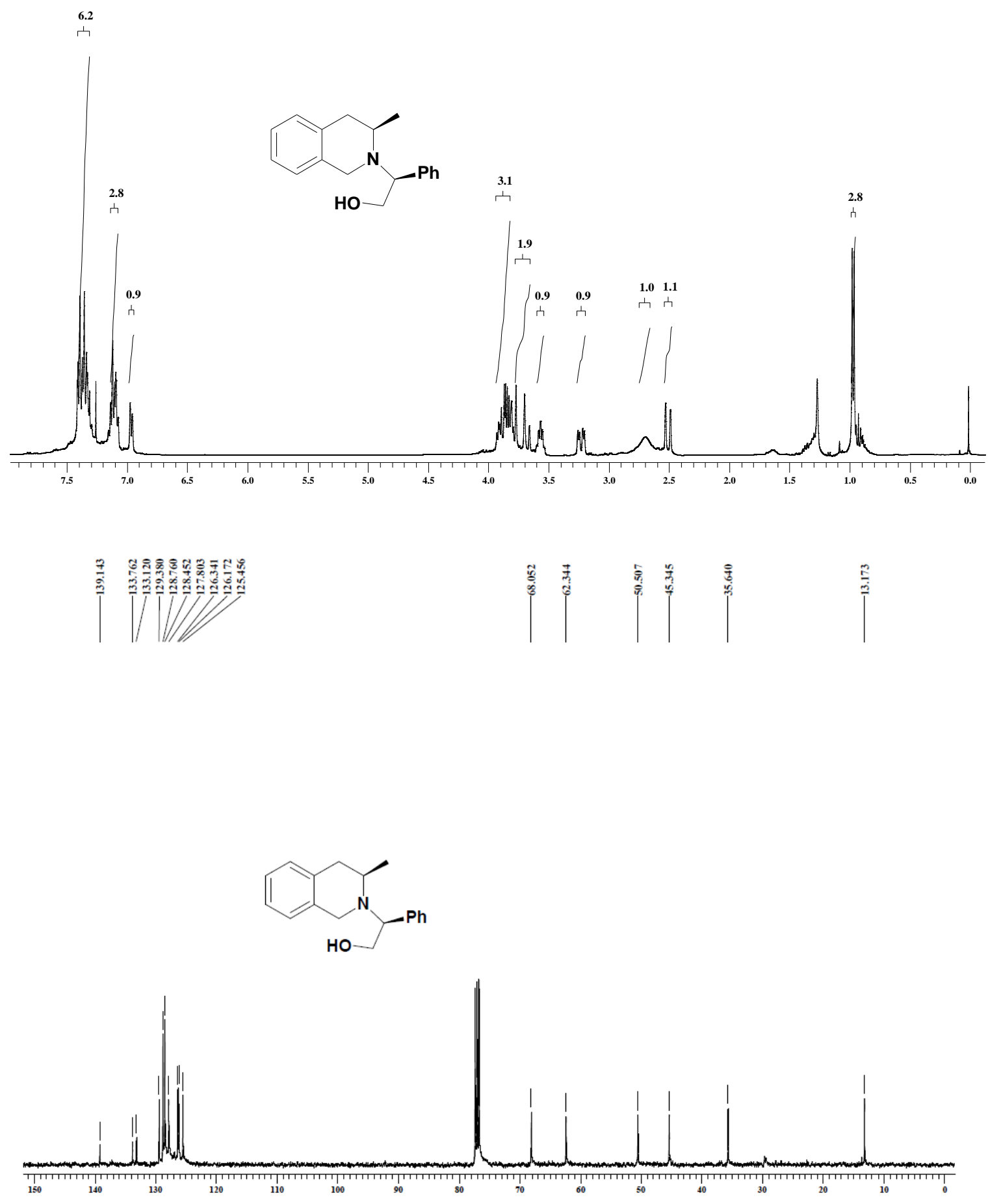
Compound 26
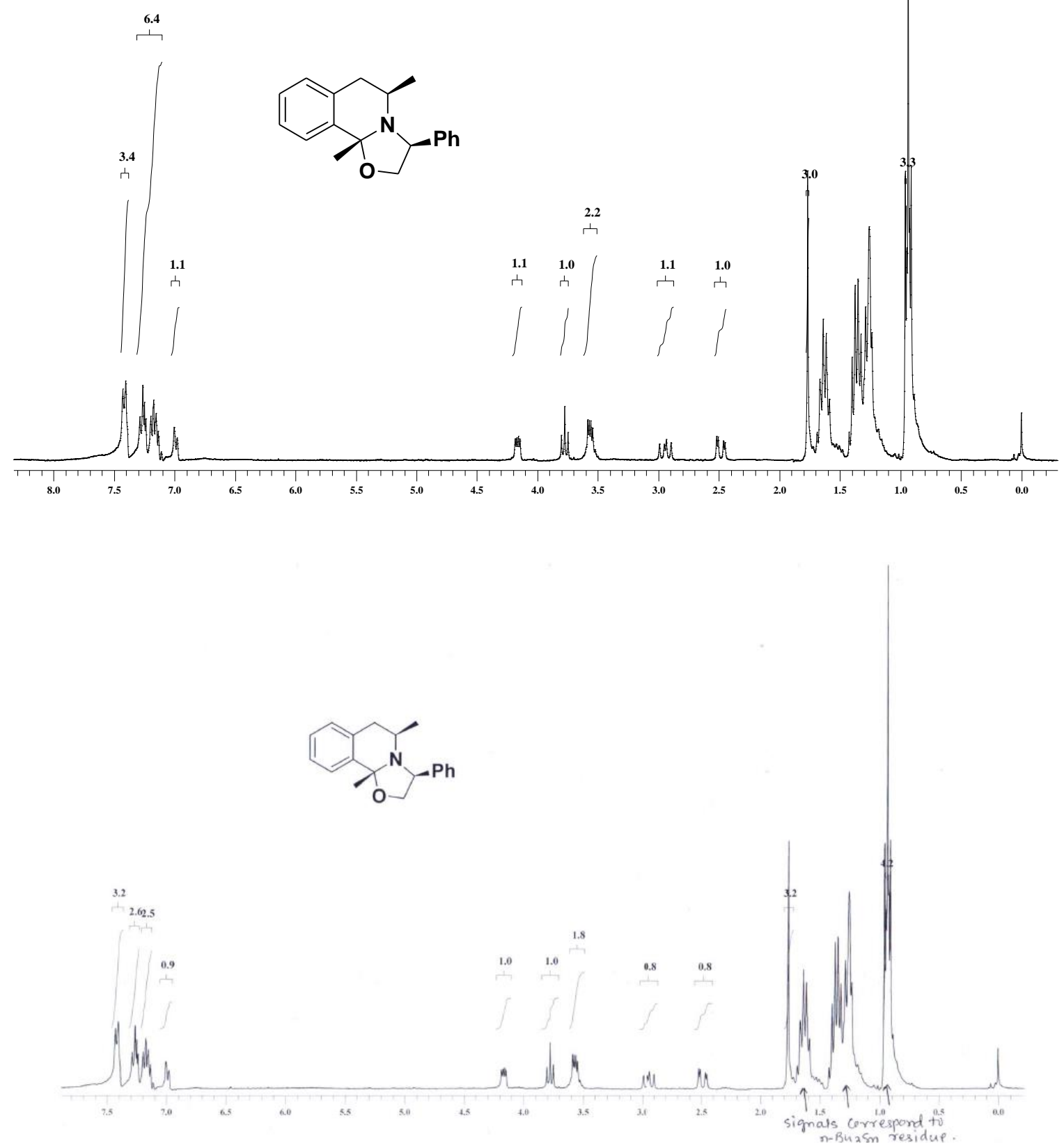


\section{Compound 26}
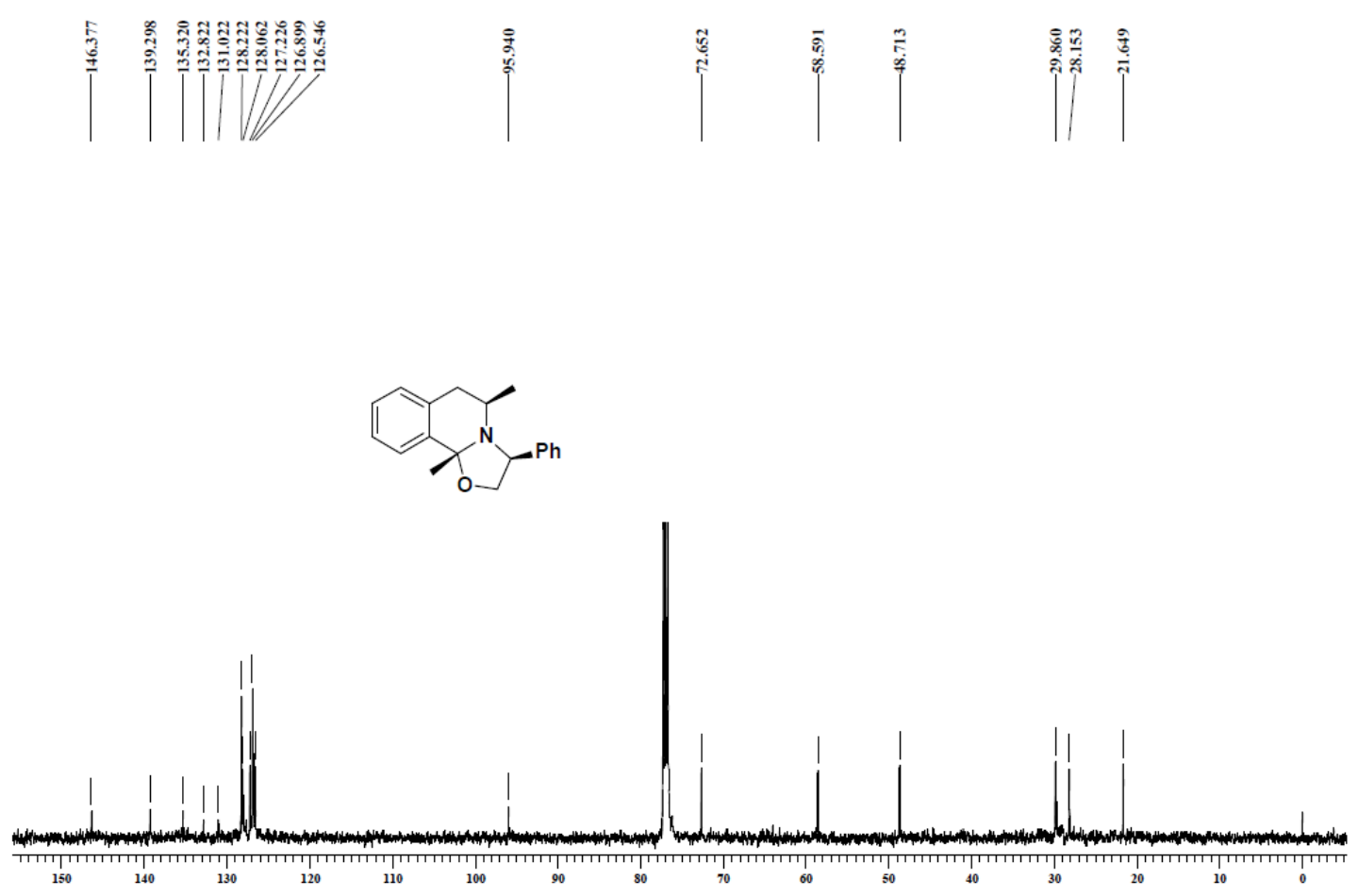
Compound 32
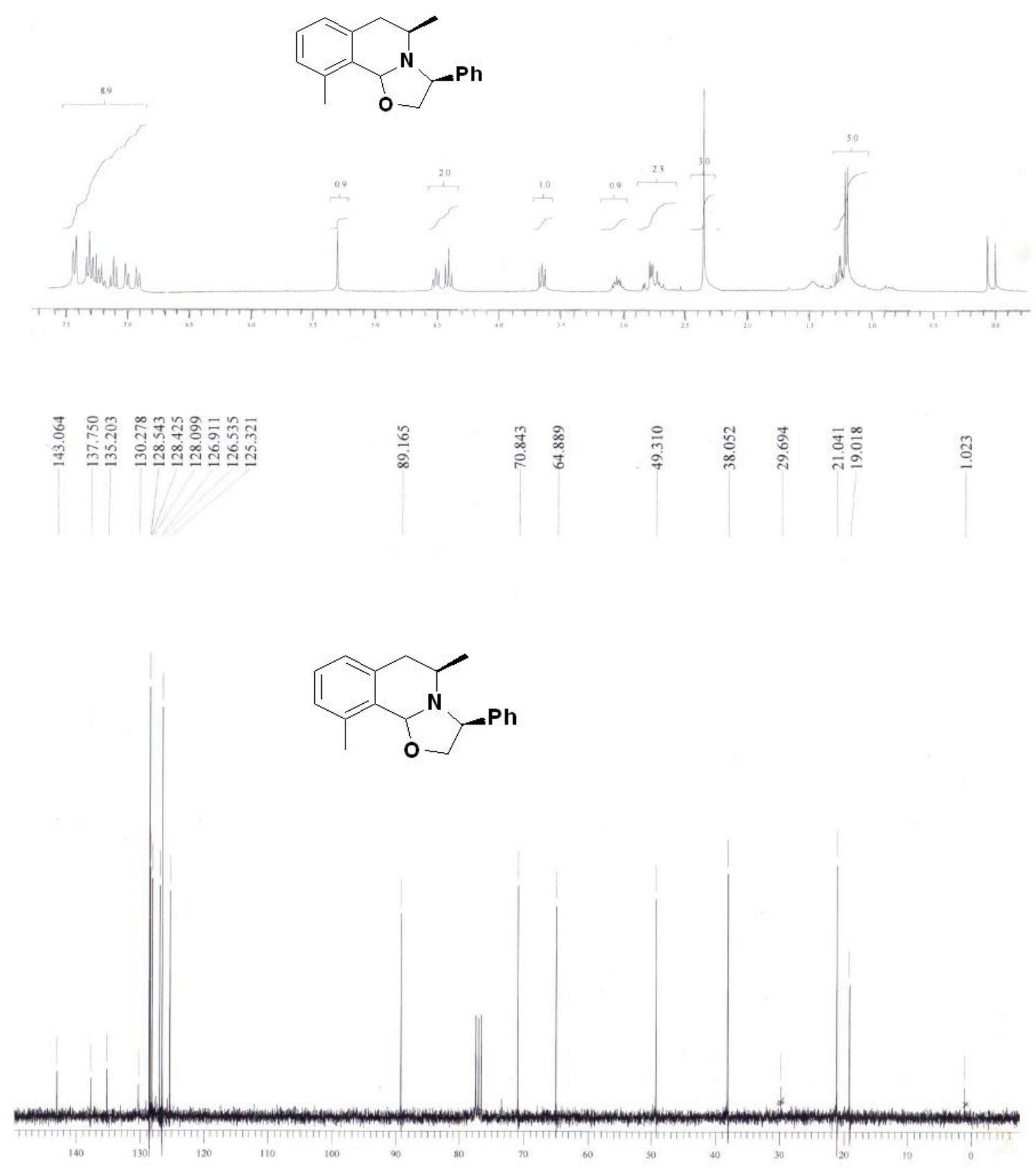


\section{Compound 10}
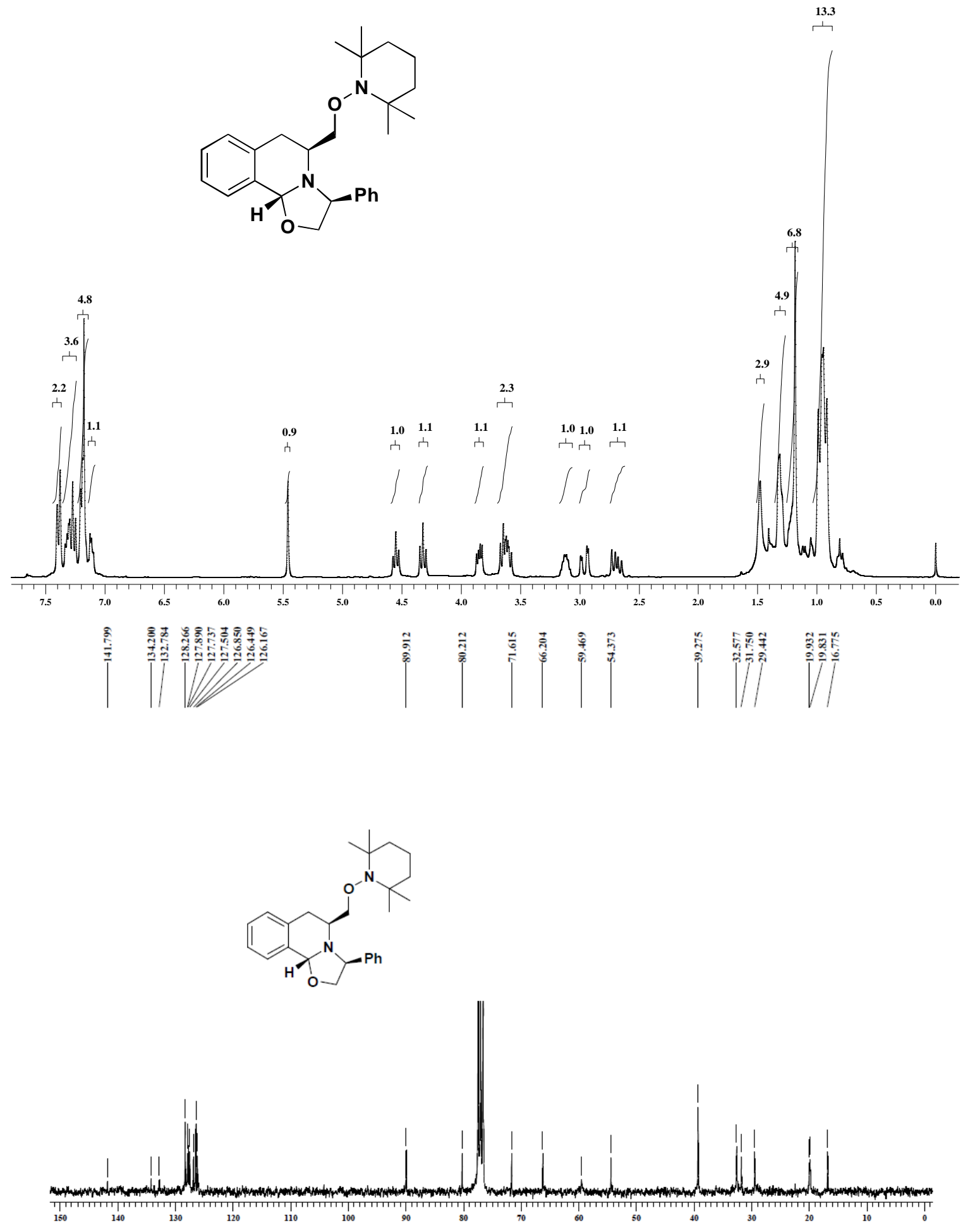


\section{Compound 11}
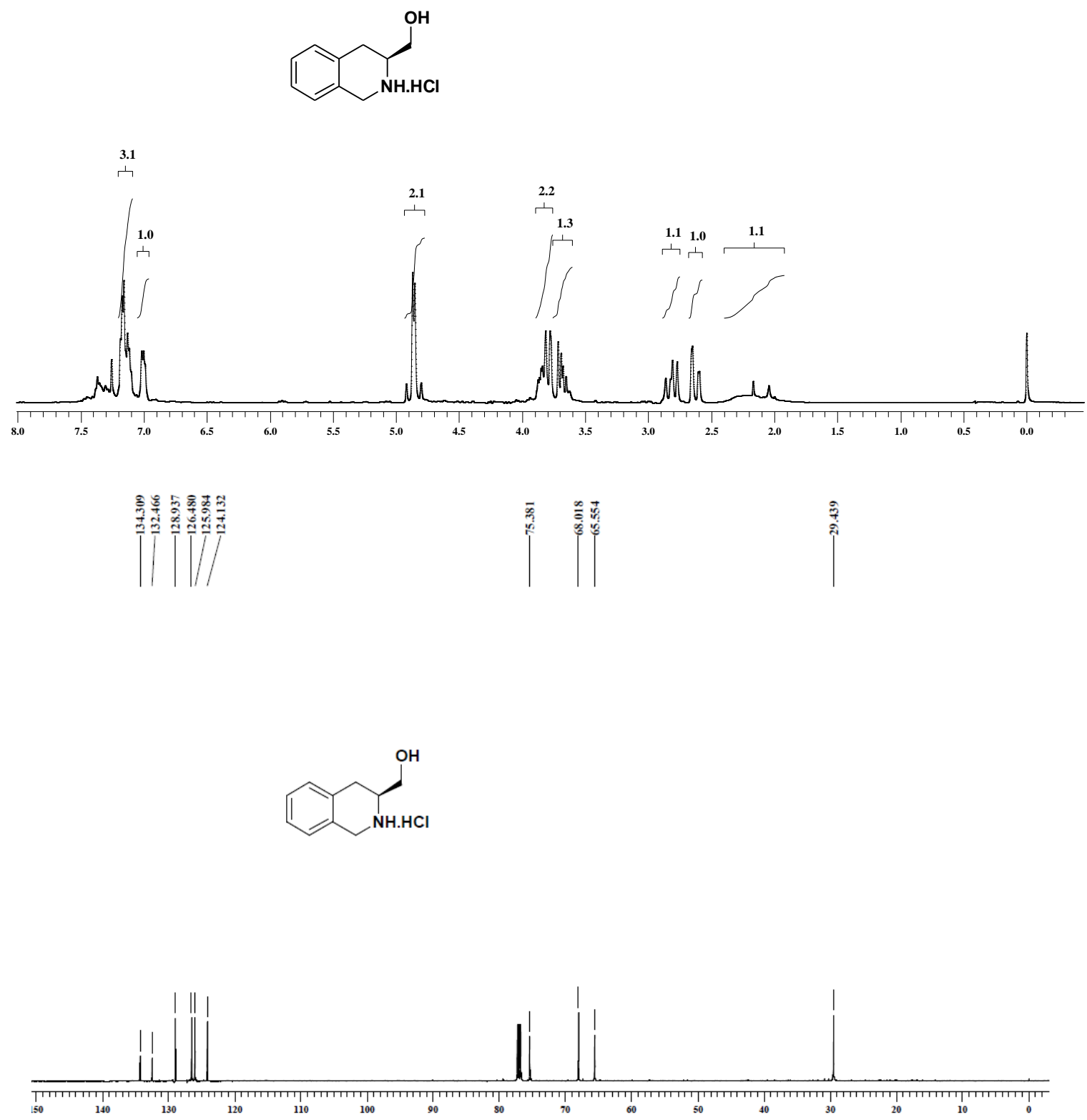

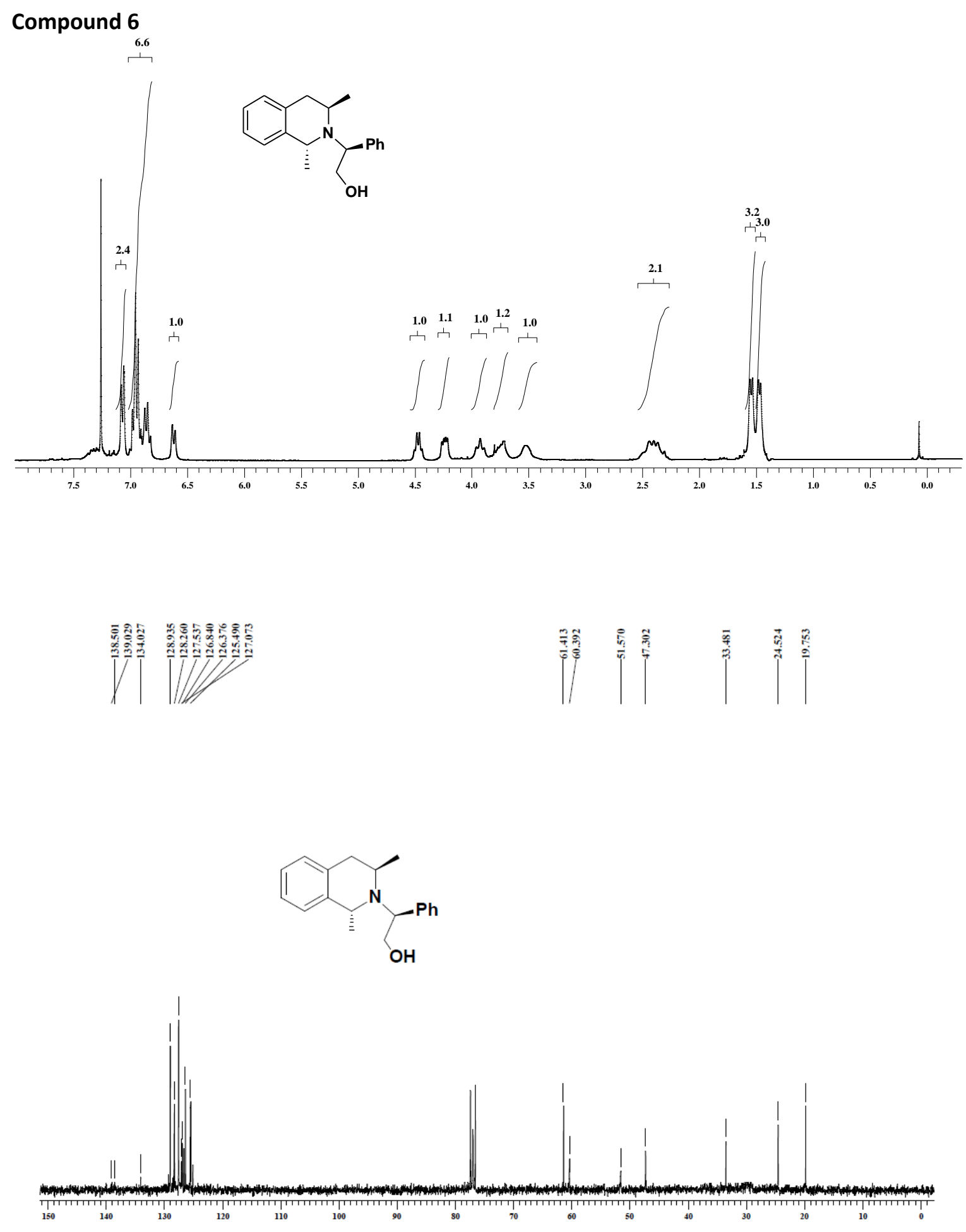
Compound 6

08-029-X0010-SR-PSHE-TOESY -050709

Archive directory: /export/home/vnar2/vnarsys/tate sulse sequence: xotsy
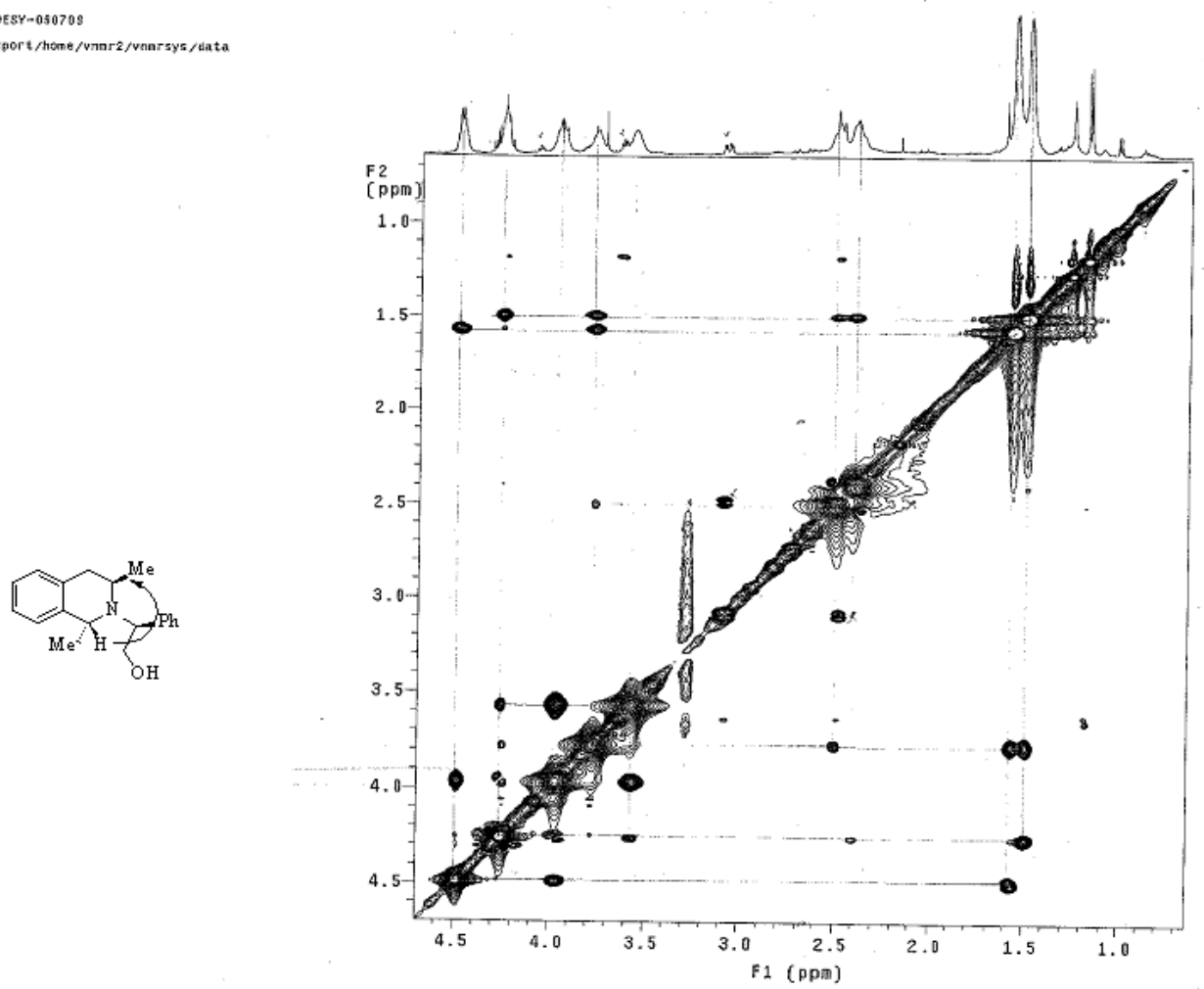


\section{Compound 7}
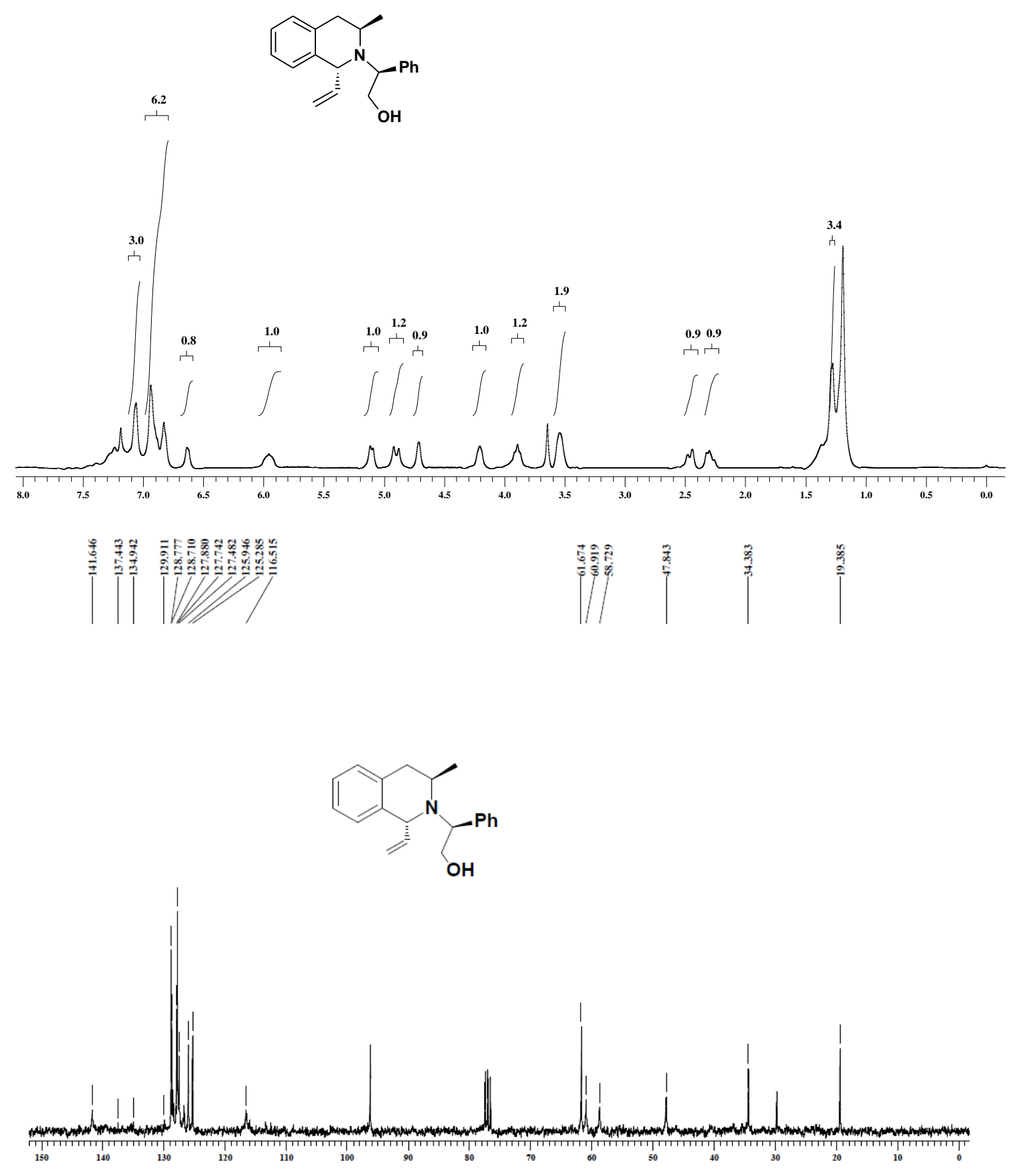


\section{Compound 8}
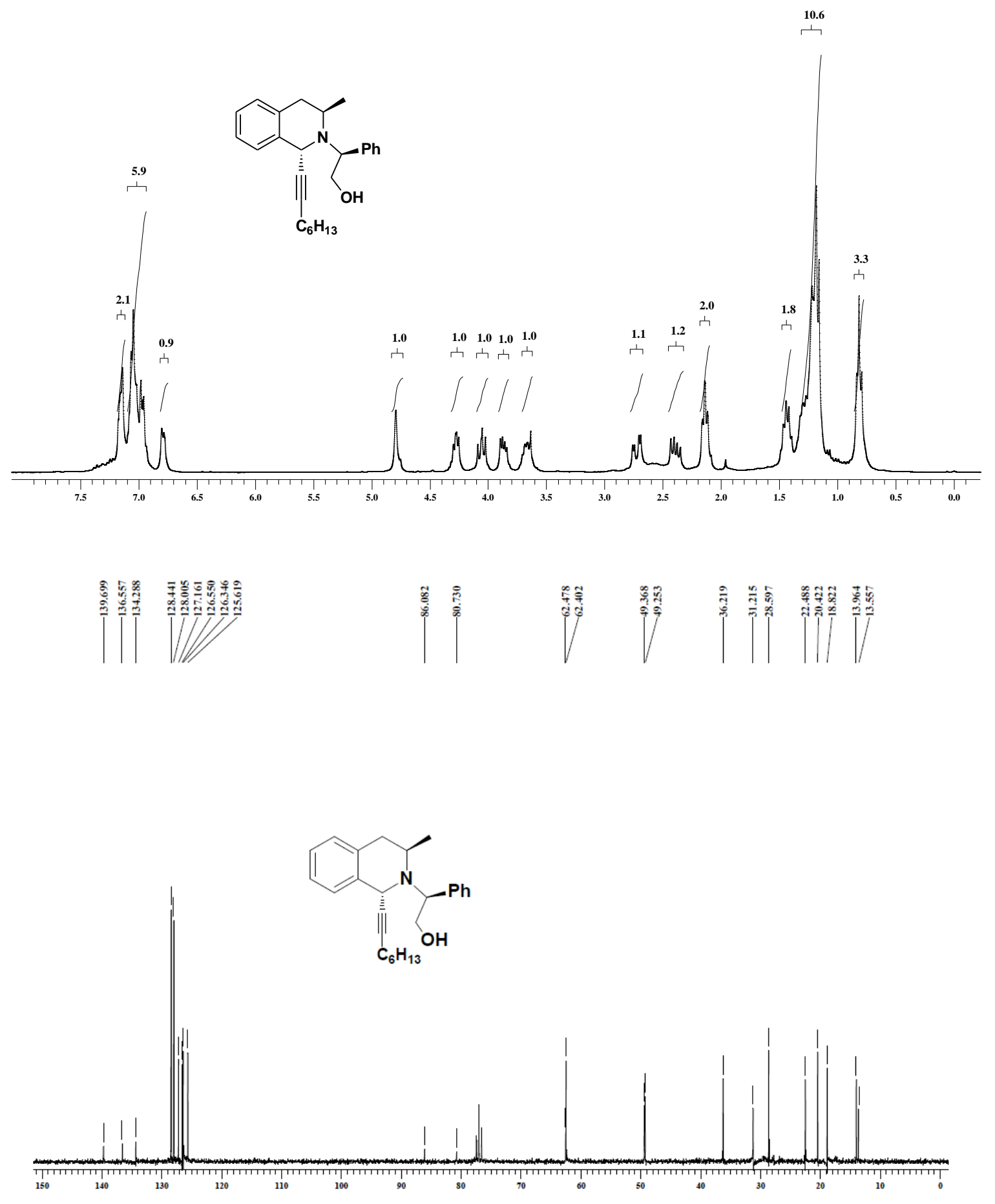


\section{Compound 27}
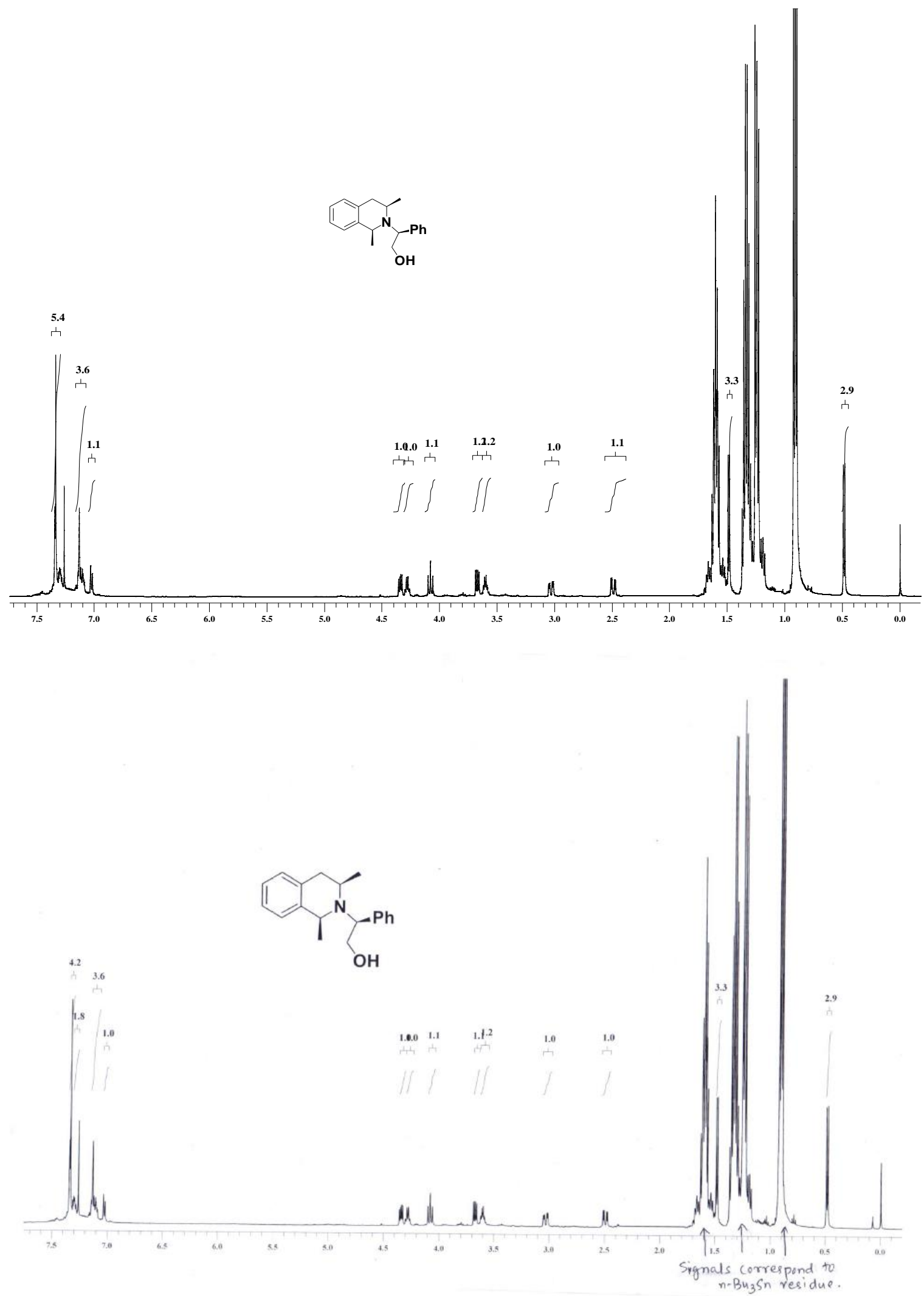
Compound 27
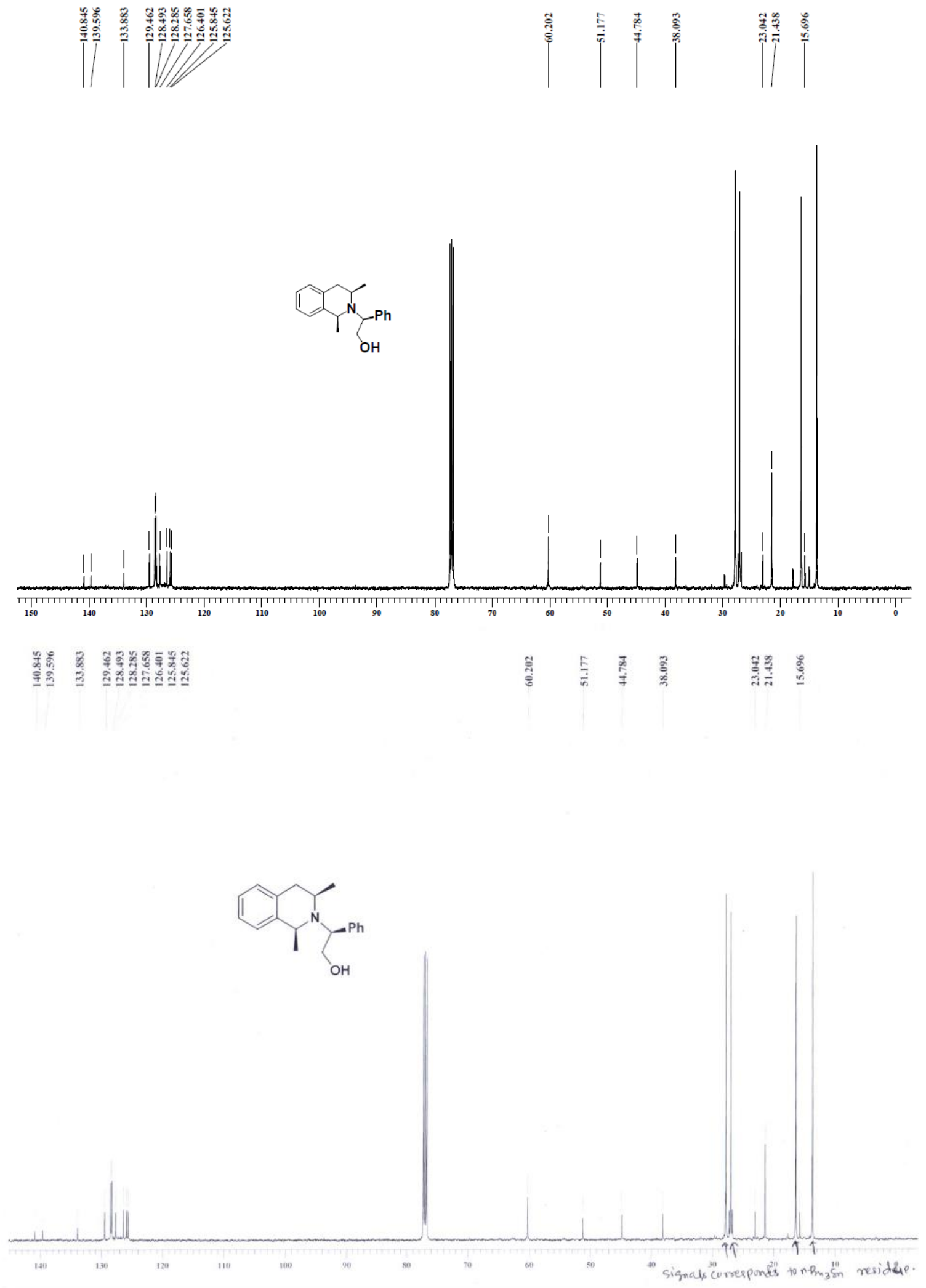
Compound 27

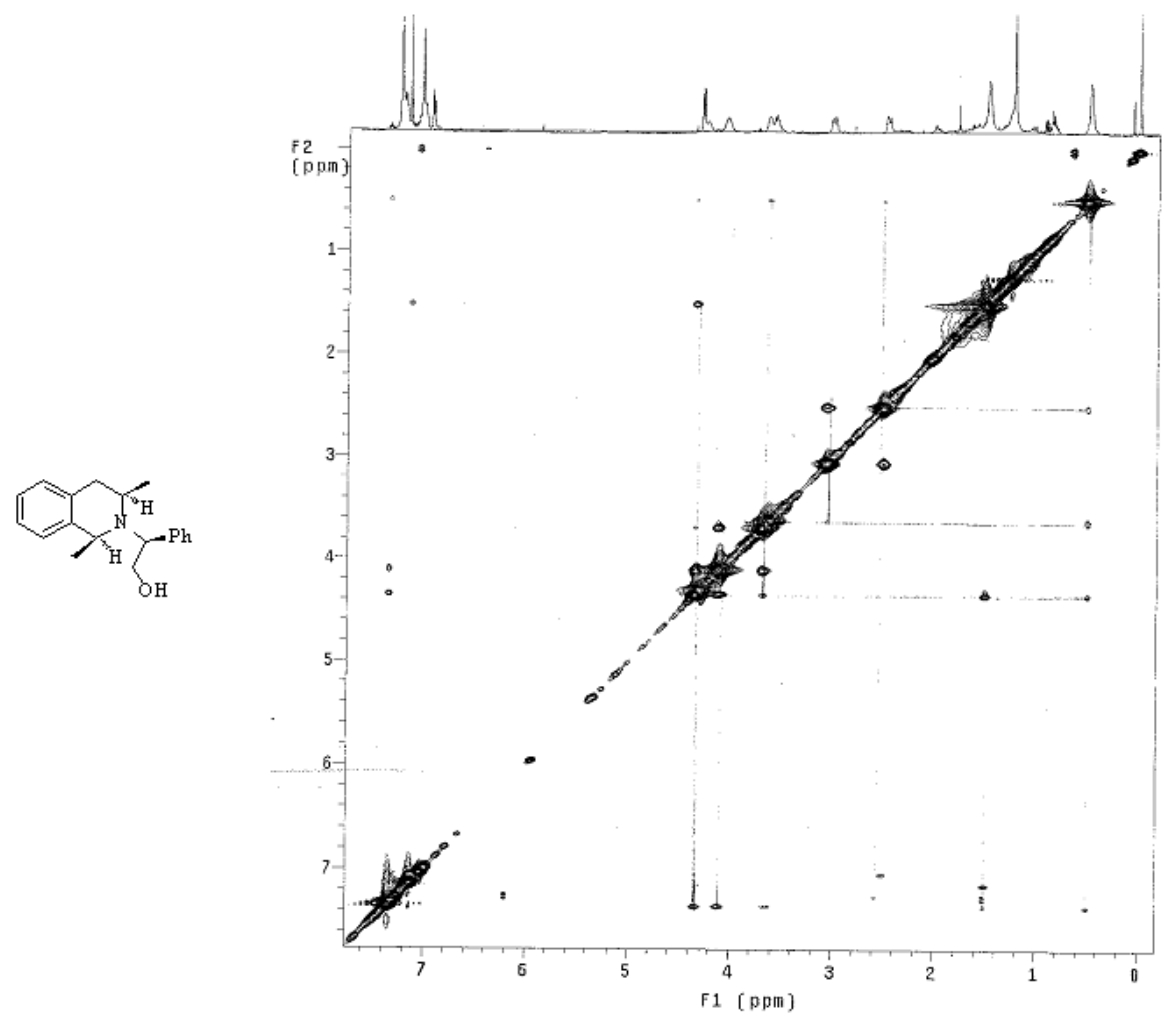



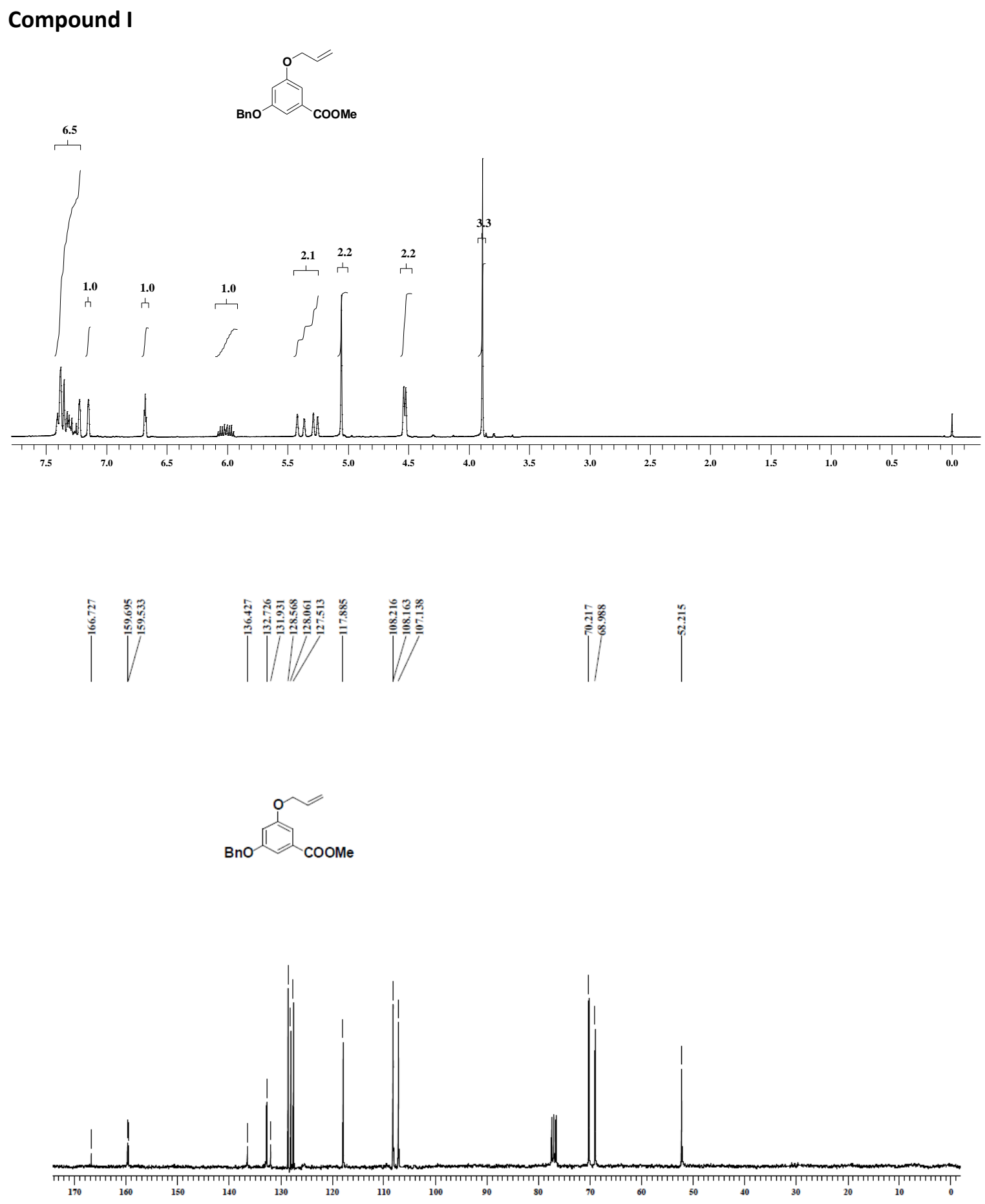


\section{Compound II}
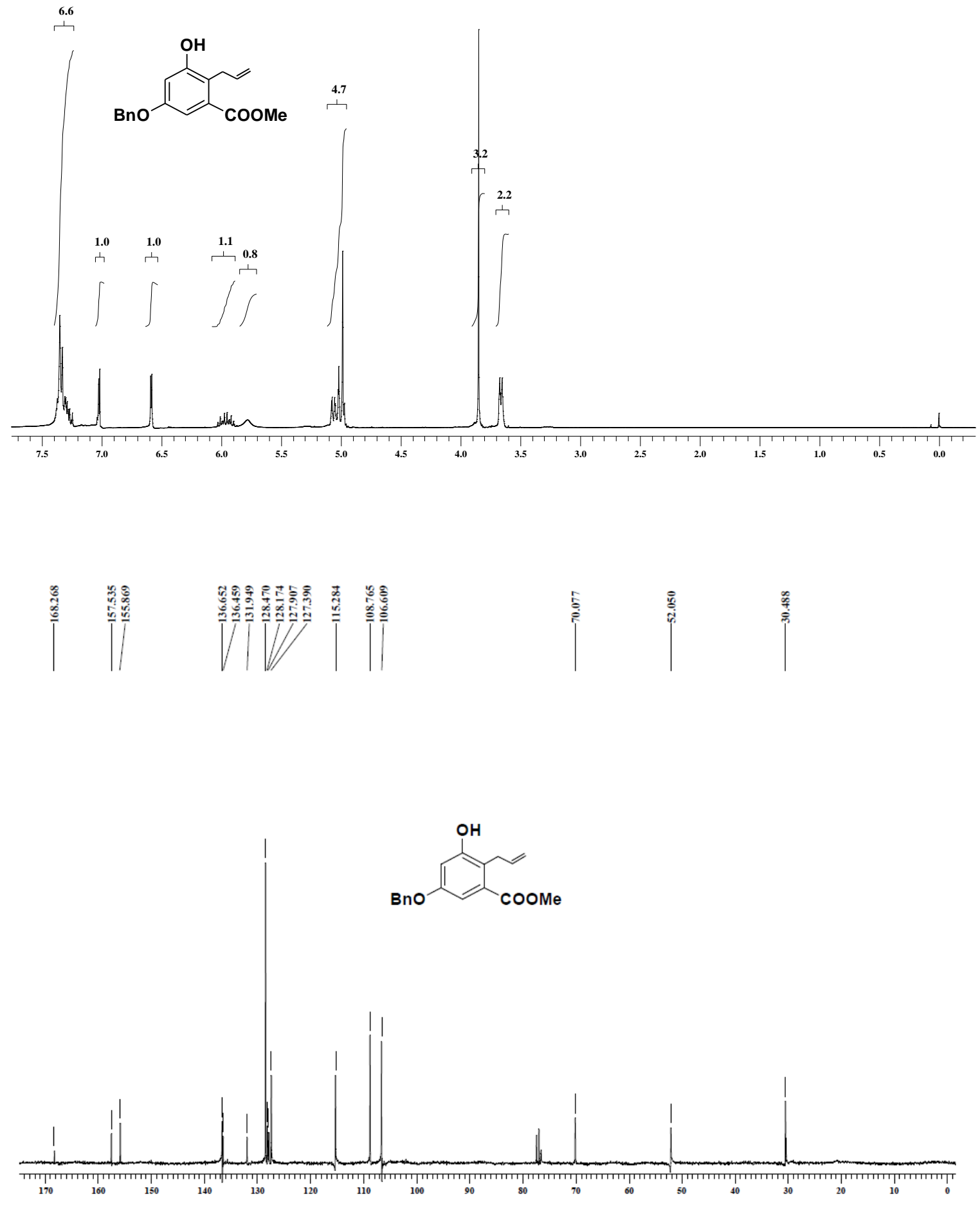


\section{Compound III}
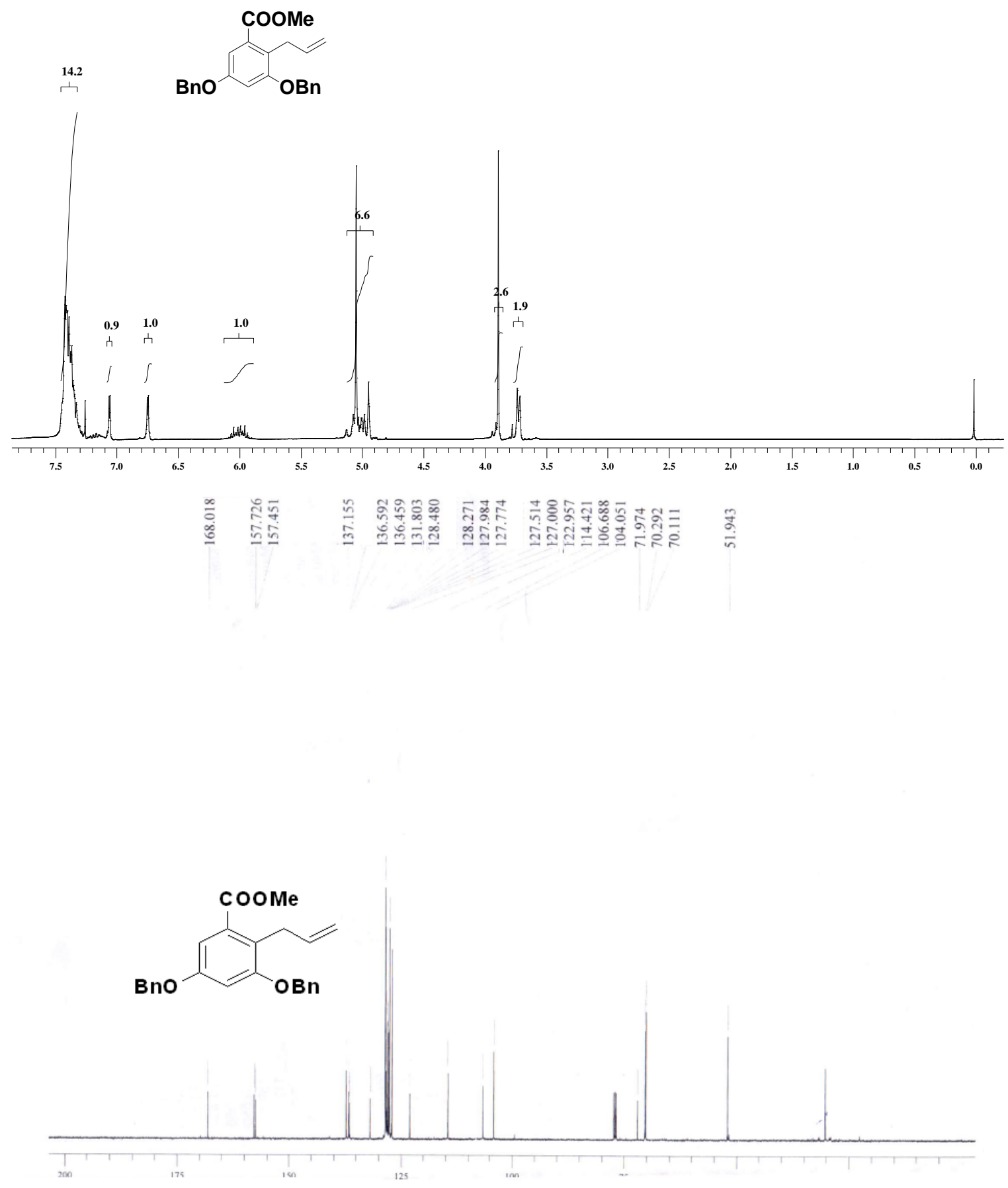


\section{Compound IV}
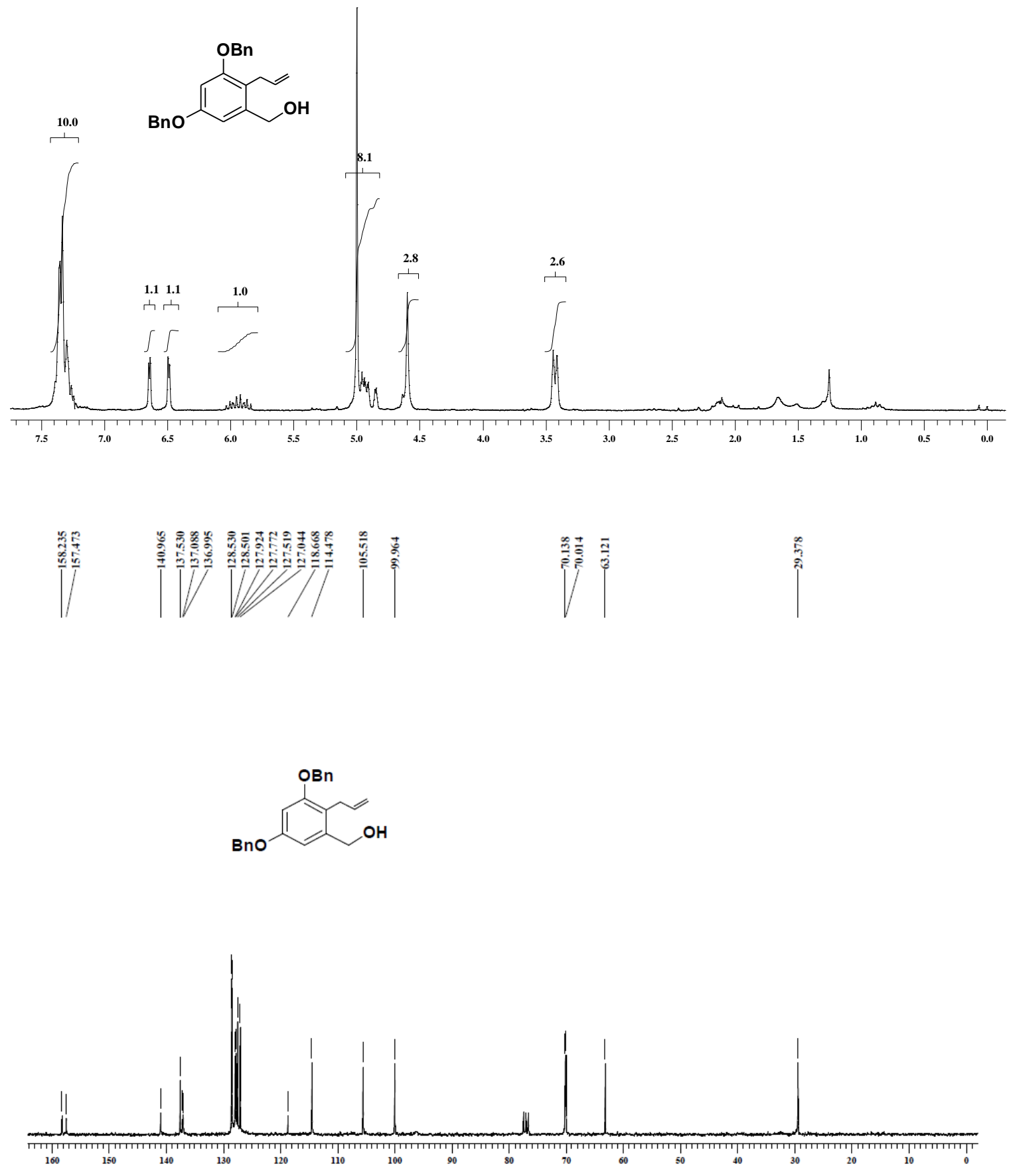

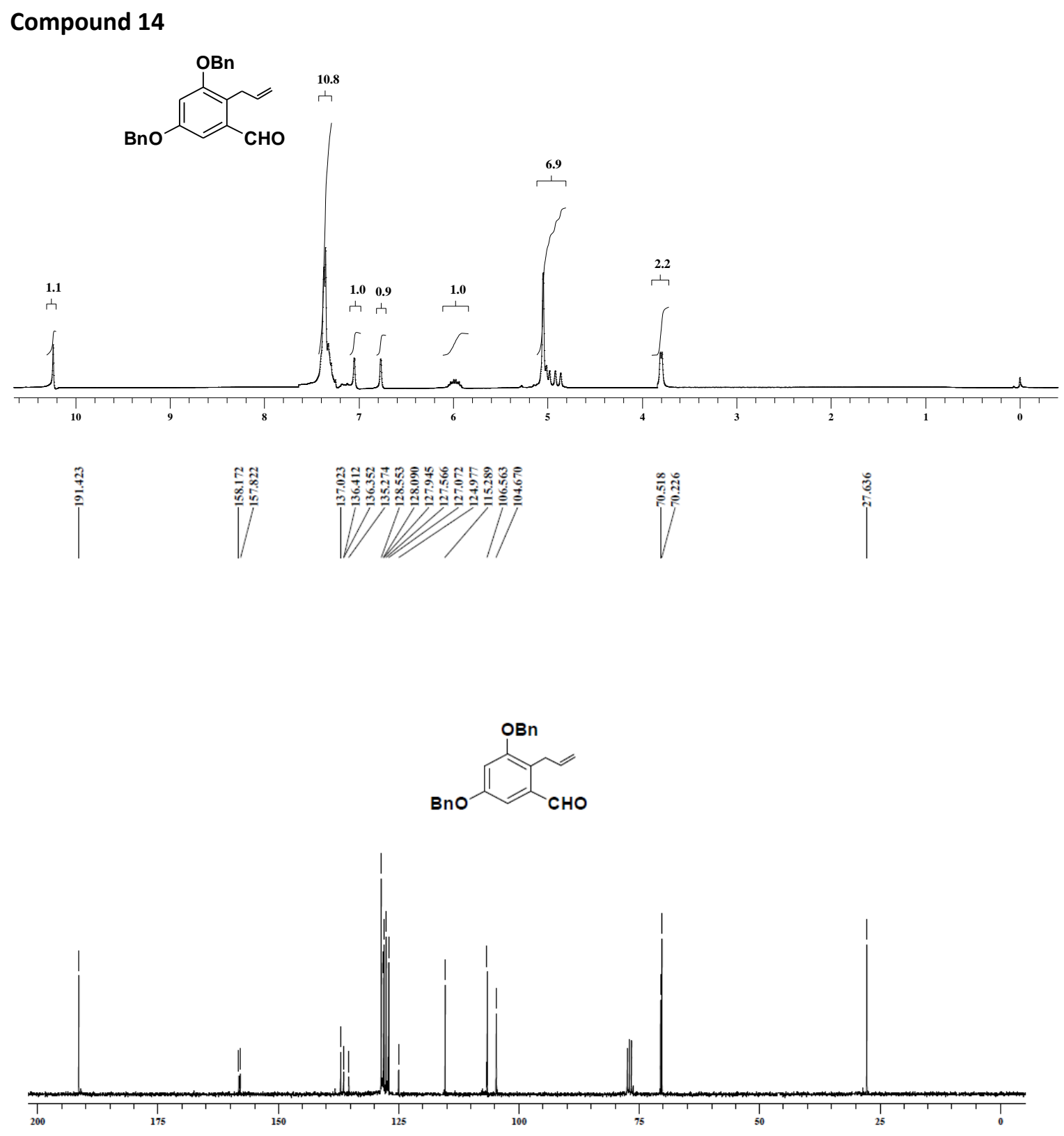


\section{Compound VI}

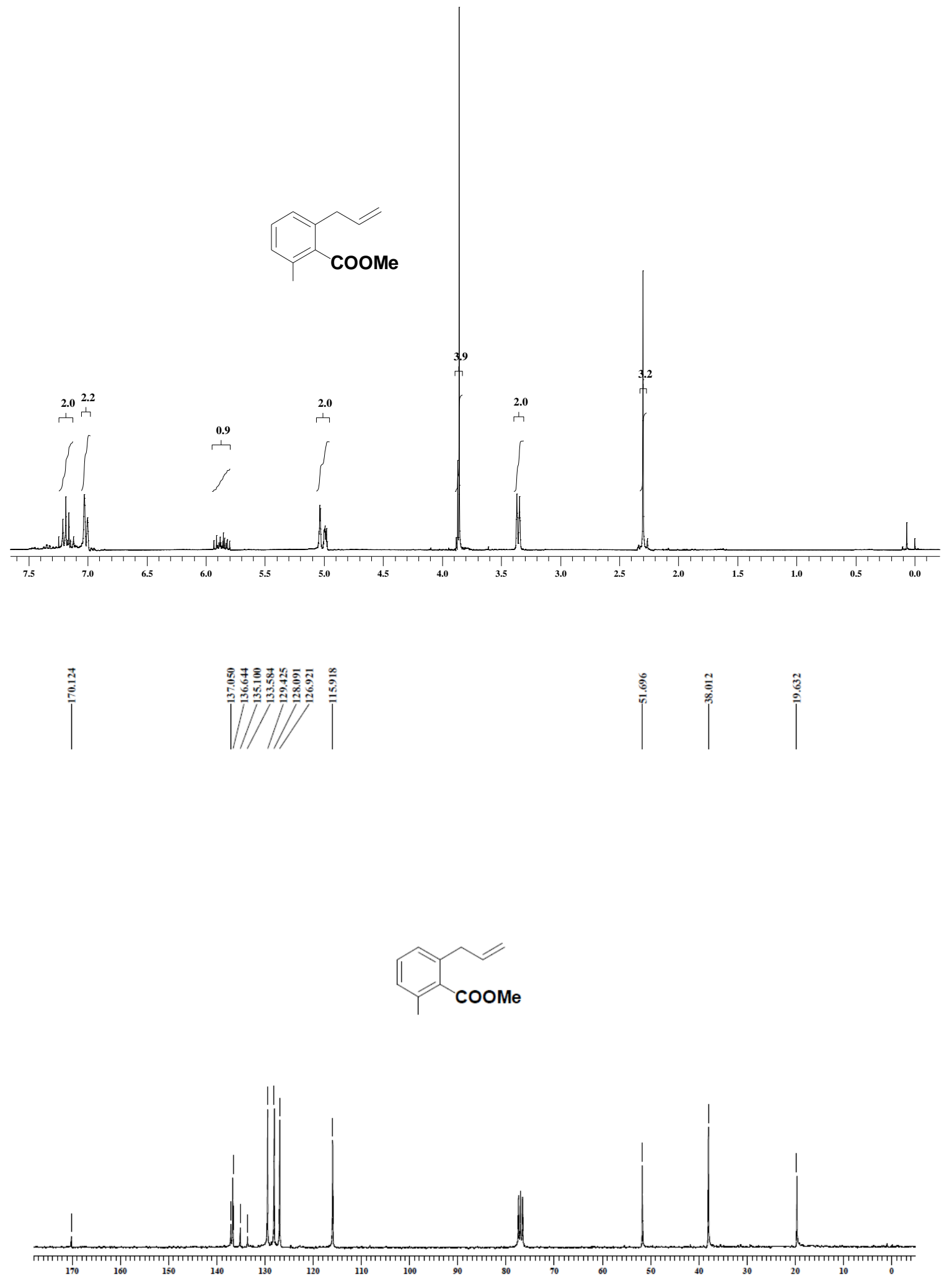




\section{Compound VII}
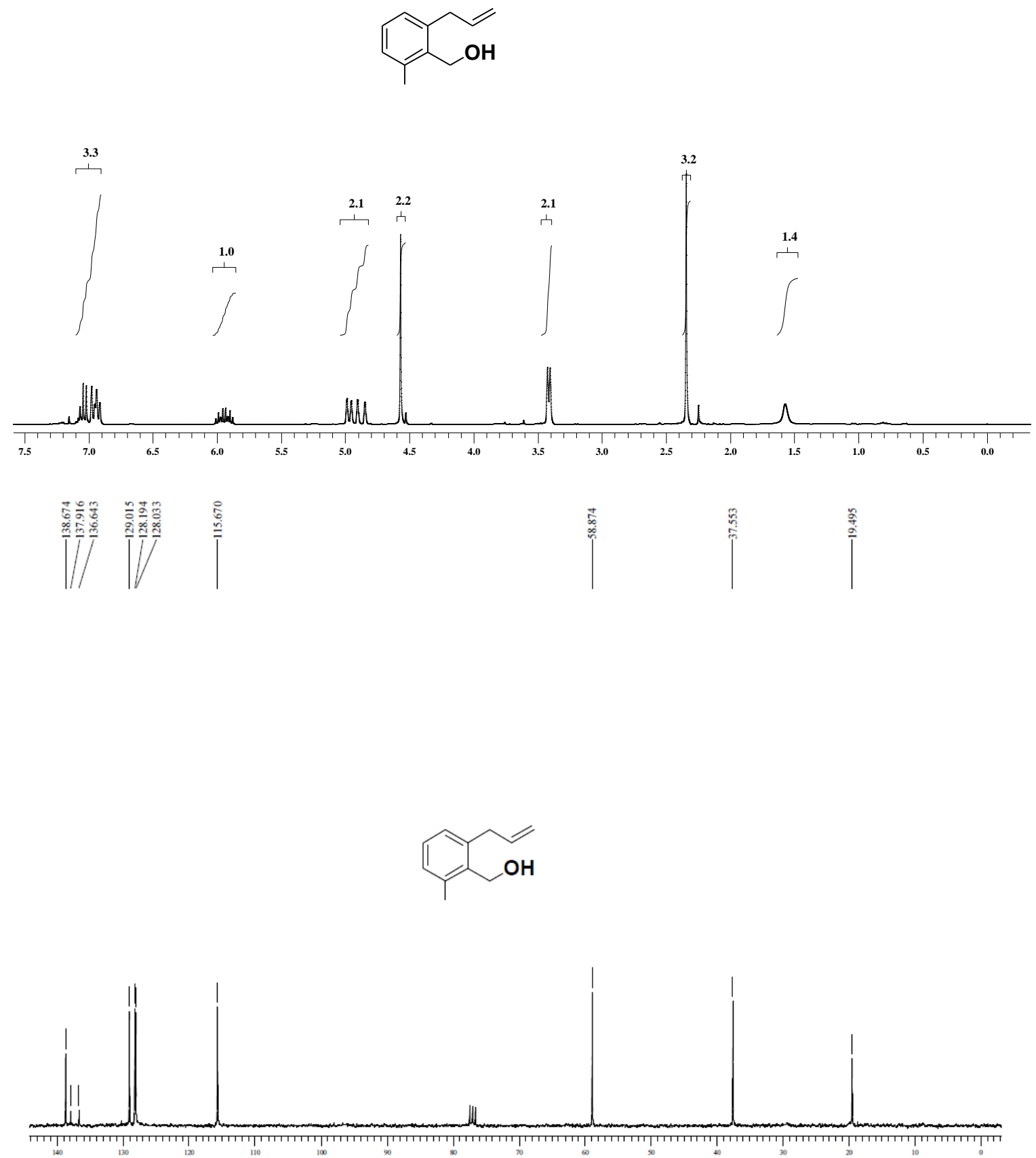


\section{Compound 16}
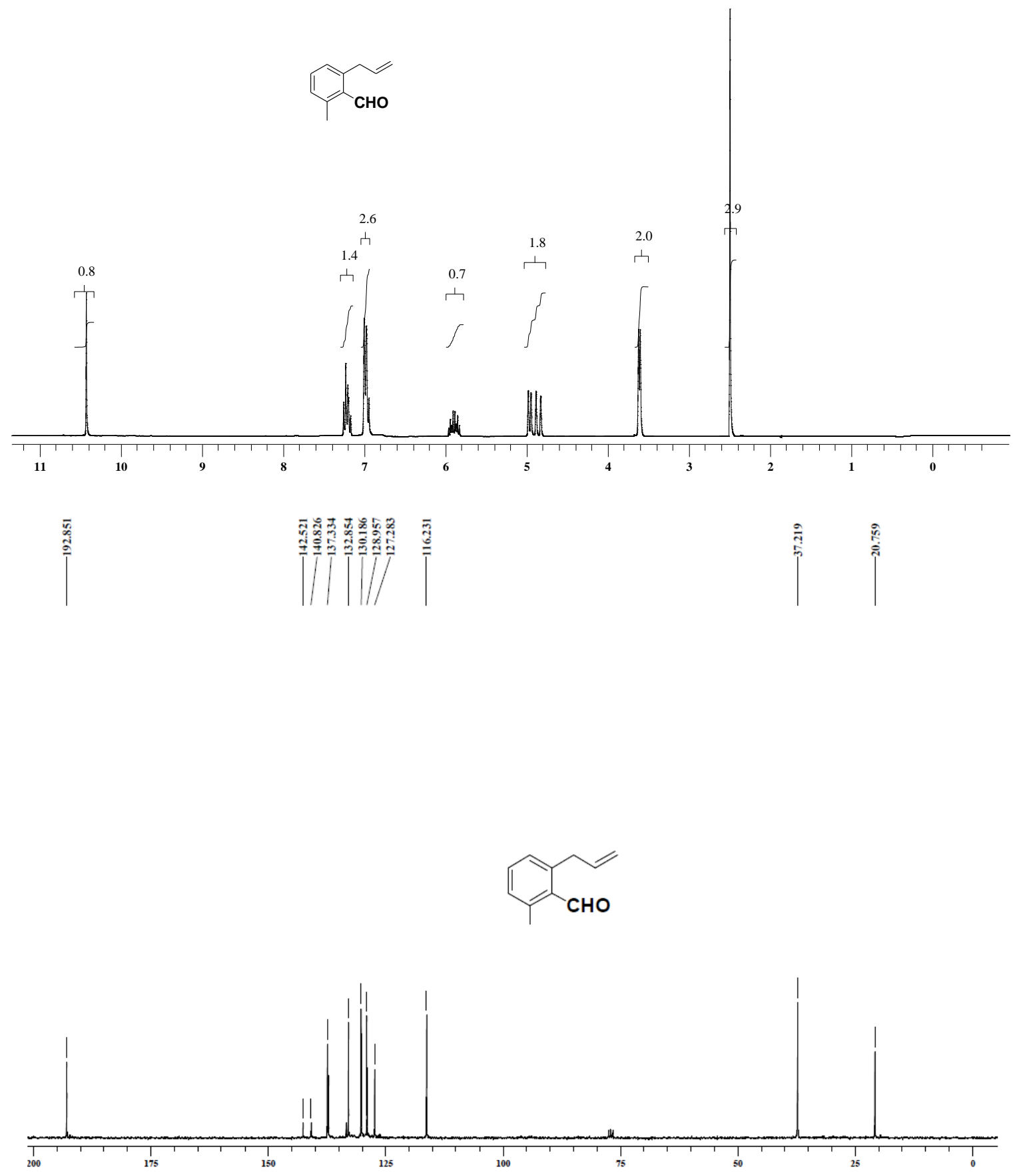
Compound 18
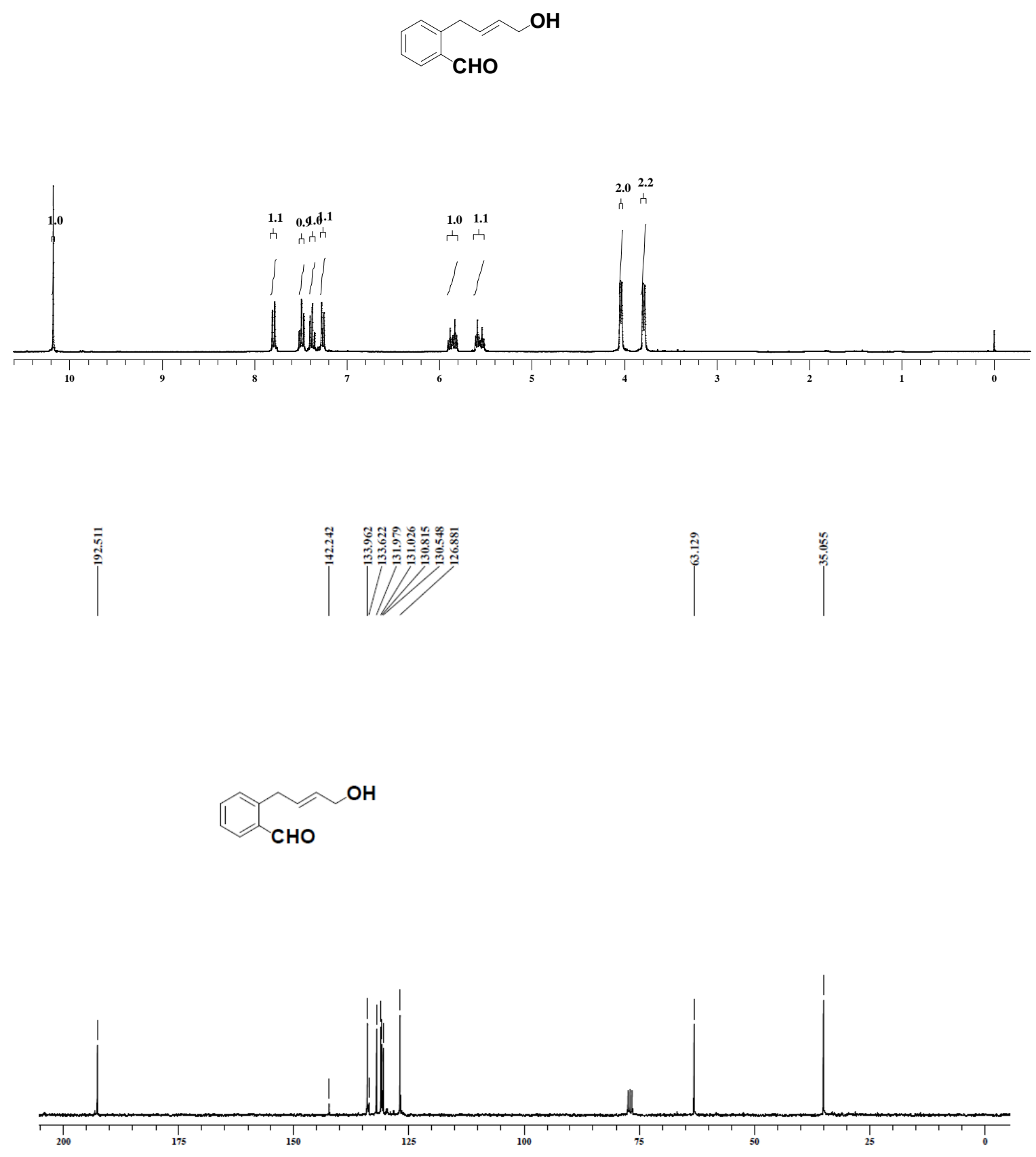


\section{Compound 19}
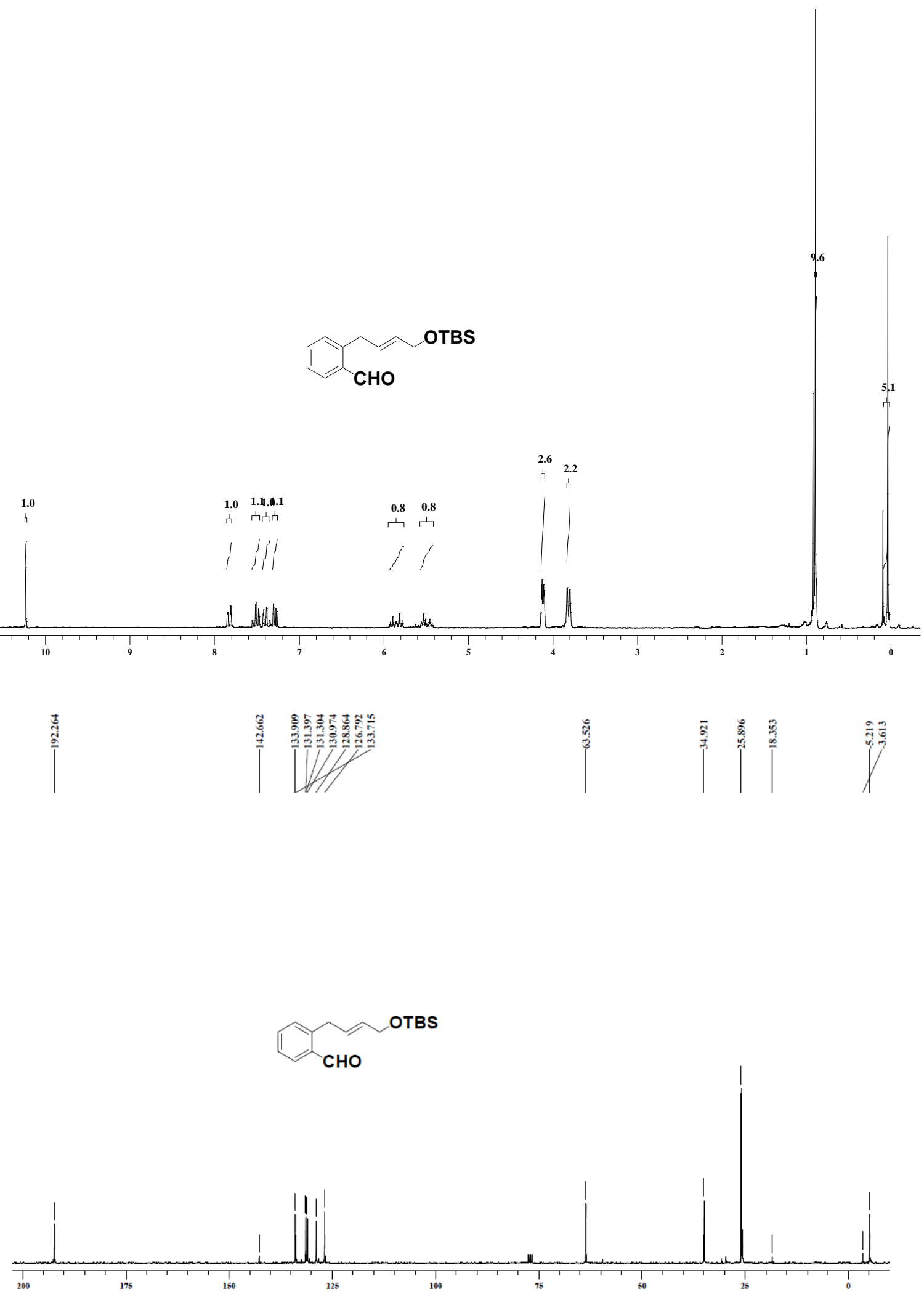


\section{Compound 33}
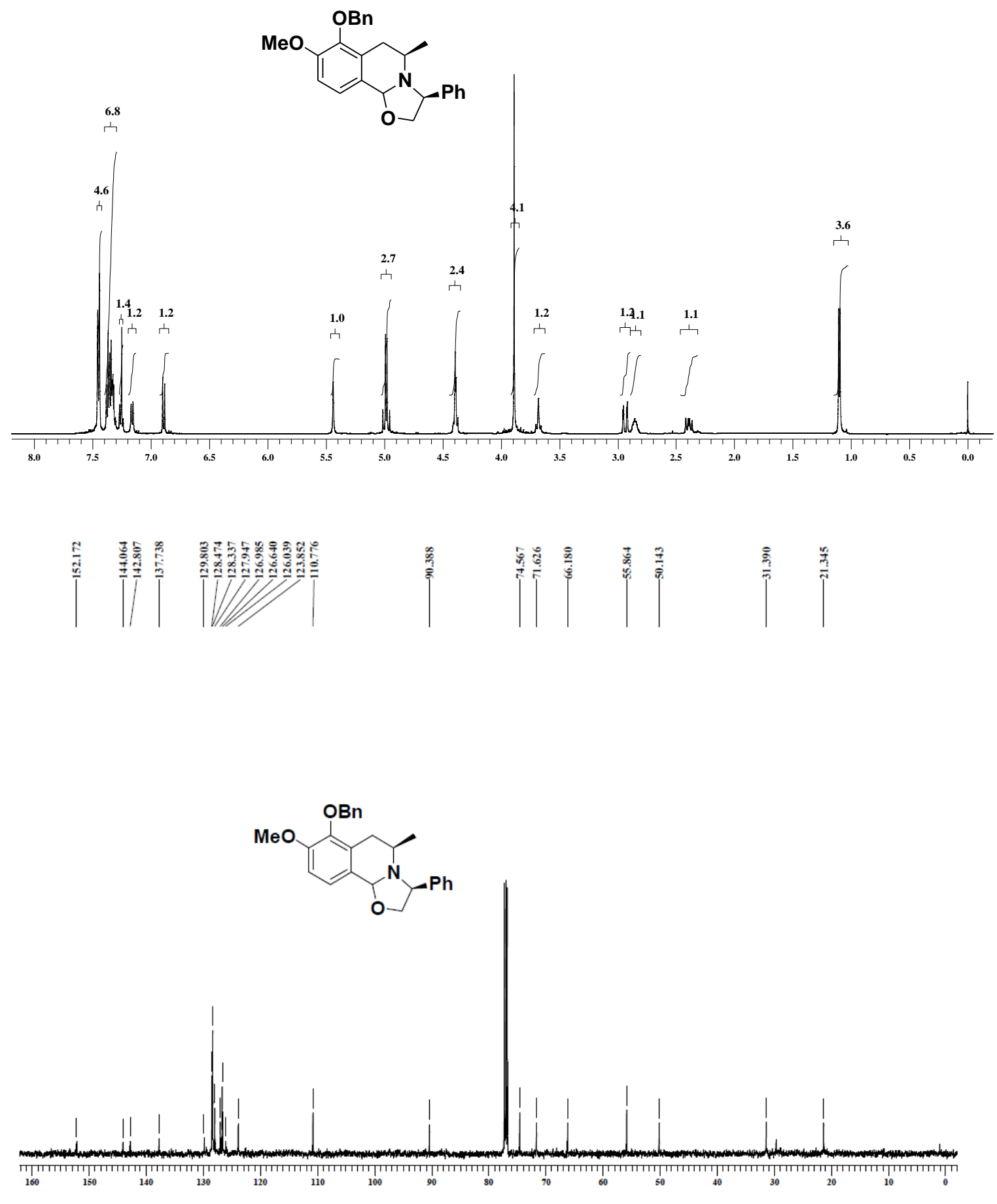
Compound $\mathbf{3 0}$
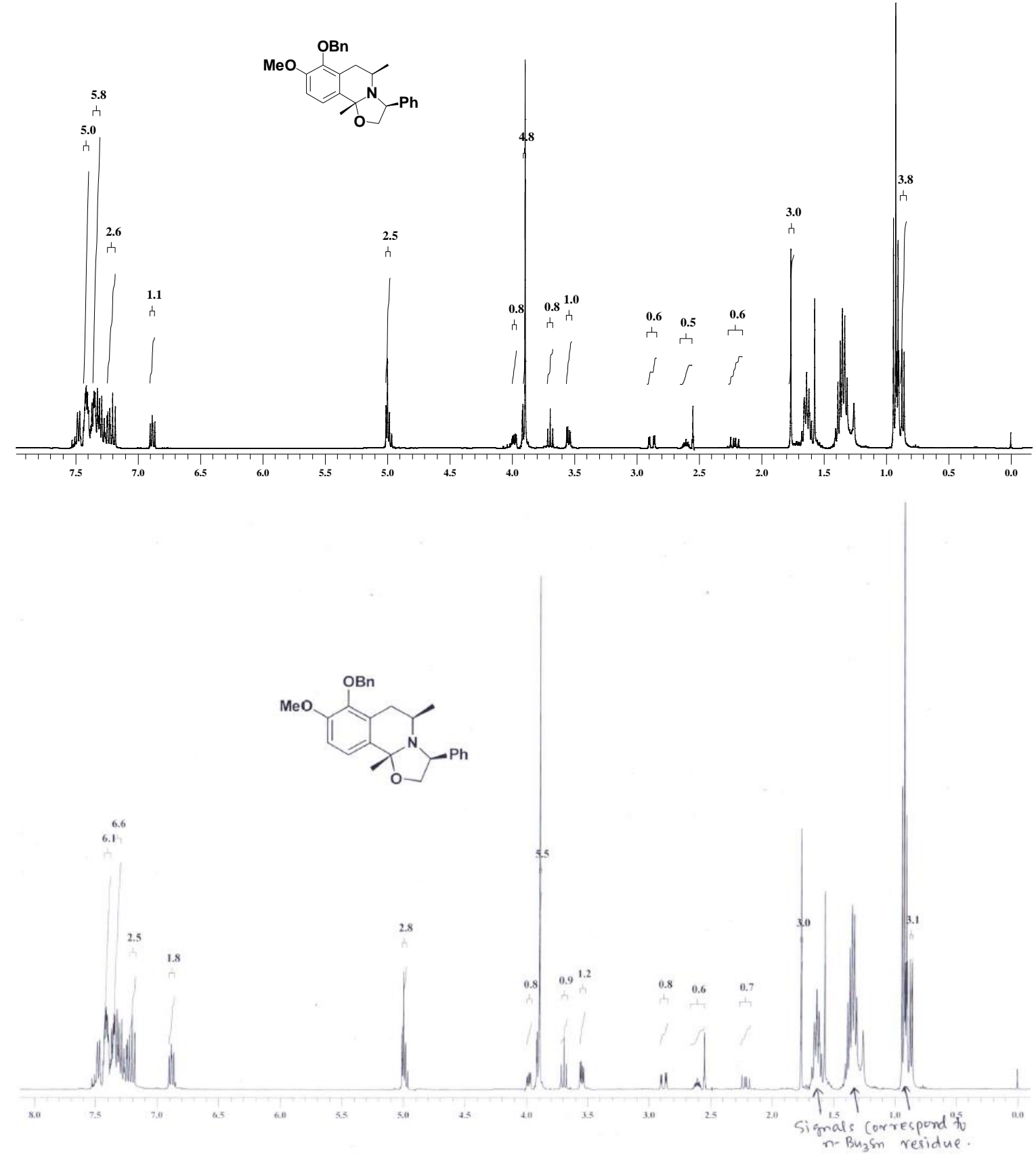


\section{Compound 30}
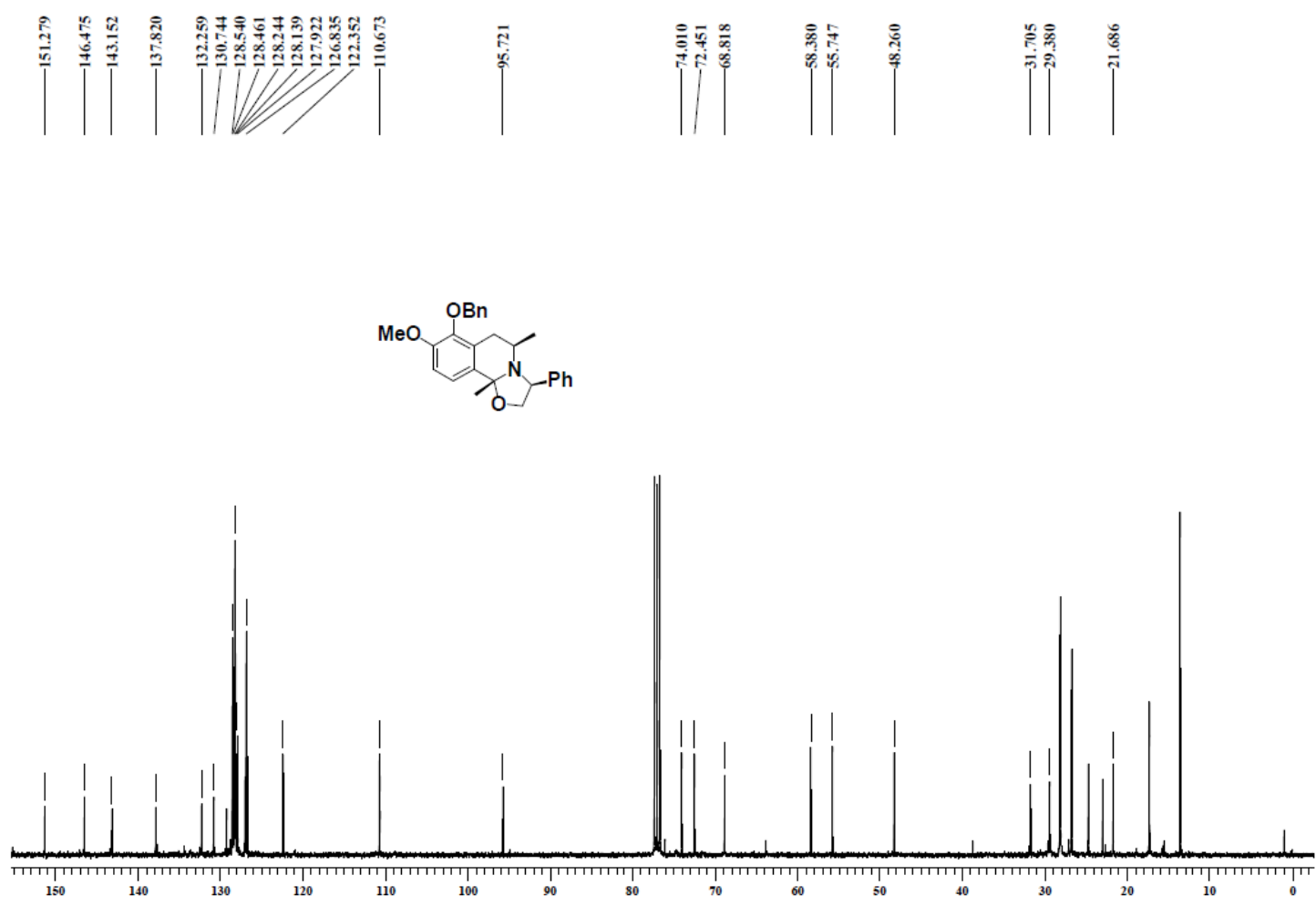

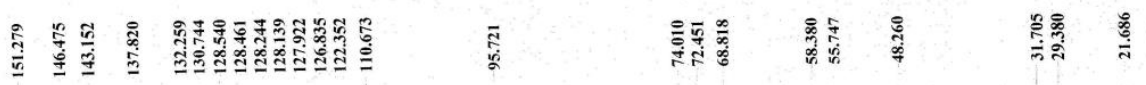
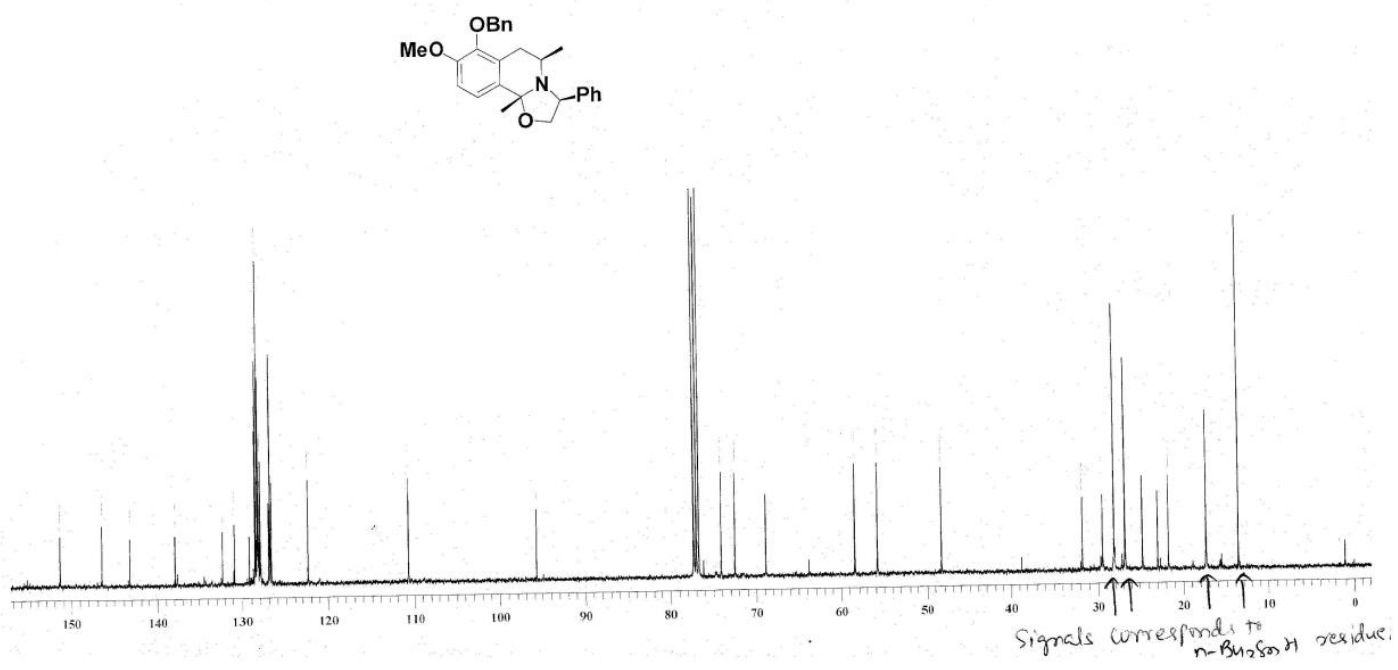


\section{Compound 31}
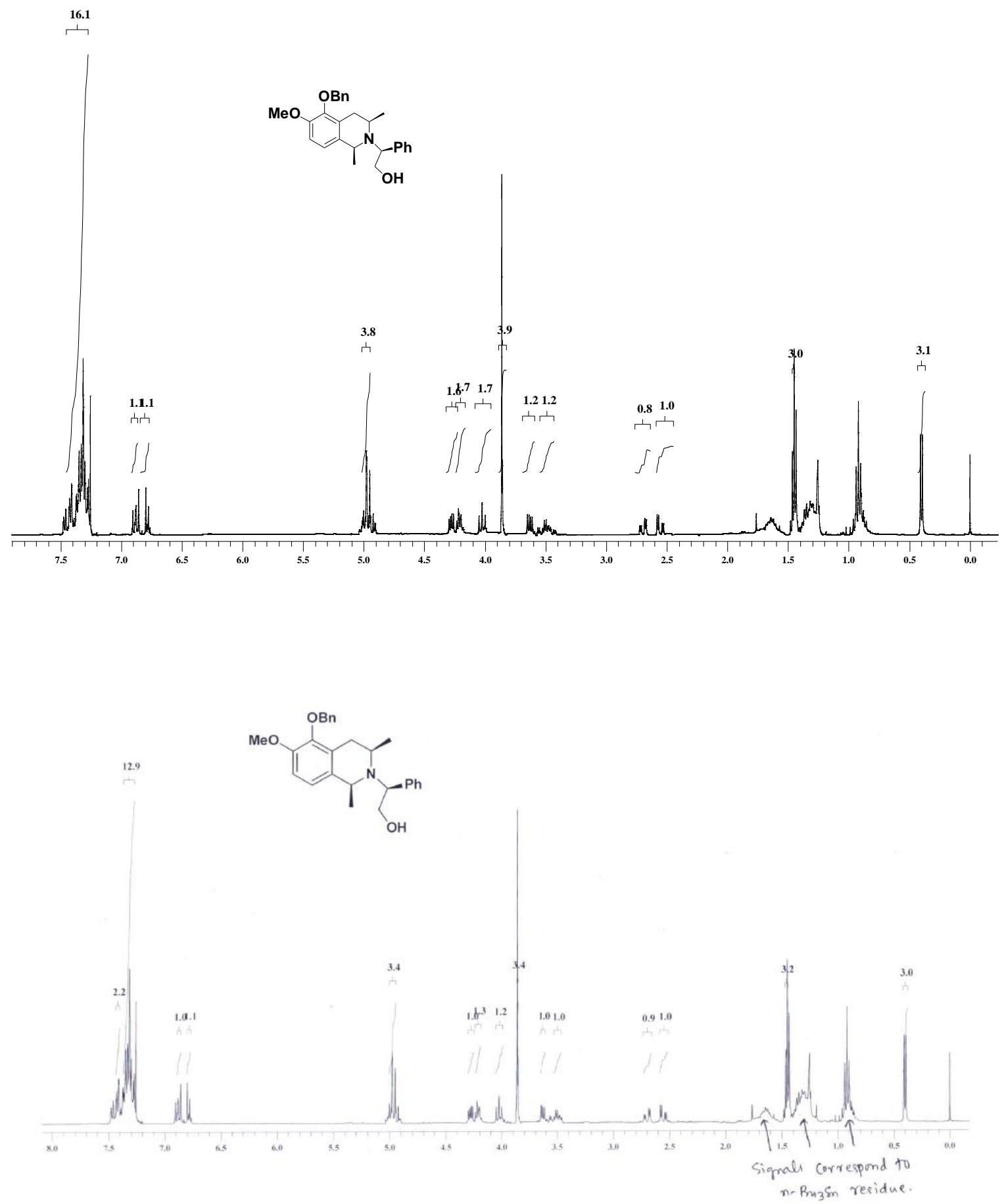


\section{Compound 31}
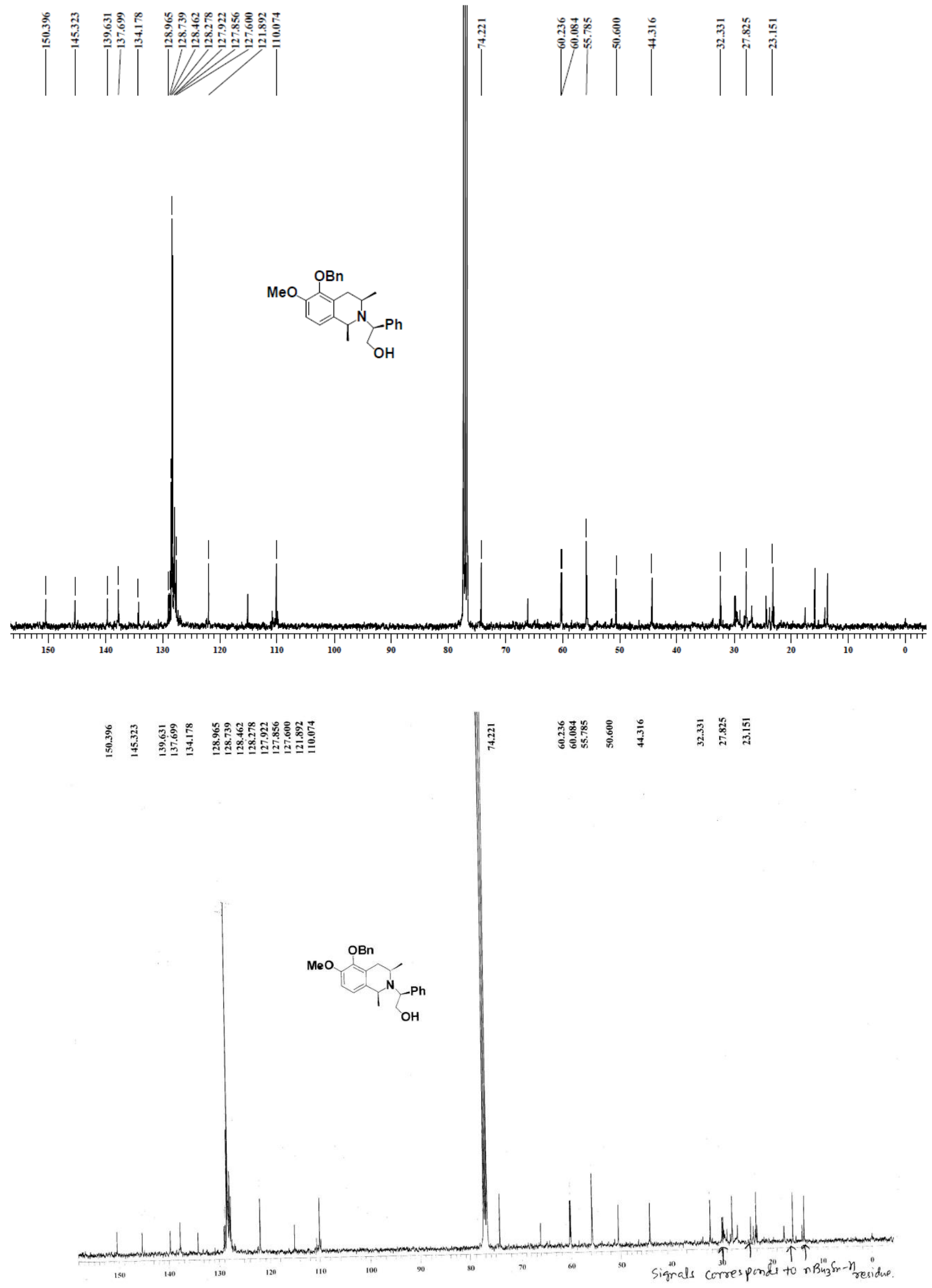